Article

\title{
Conceptualizing Sustainably Produced Food for Promotional Purposes: A Sustainable Marketing Approach
}

\section{Cecilia Solér}

School of Business, Economics and Commercial Law, University of Gothenburg, Box 600, Göteborg 40530, Sweden; E-Mail: cecilia.soler@handels.gu.se; Tel.:+46-317-865-611

Received: 5 January 2012; in revised form: 4 February 2012 / Accepted: 14 February 2012 /

Published: 1 March 2012

\begin{abstract}
Progress in transforming current food consumption and production practice in a sustainable direction is slow. Communicative, sustainable consumer policy instruments such as eco-labeling schemes have limited impact outside the green segment and within the mainstream market. This article asks how sustainably produced food can be described in order to promote such food. Based on six cases, it aims to conceptualize the common denominators of sustainable food production by drawing on recent literature on sustainable marketing and on food and sustainable development. Contradictions and implications in terms of labeling schemes, global sourcing and consumer food practice are discussed.
\end{abstract}

Keywords: sustainable consumption; consumer empowerment; sustainable food production

\section{Introduction}

The reported low levels of knowledge and trust among Western consumers regarding sustainably produced food is alarming [1,2]. Problem awareness, i.e., knowledge regarding food production and its relation to sustainable issues, is considered a main driver of sustainable food consumption practice $[1,3]$. Hence, the "disappointingly slow" progress in consumption of sustainable (e.g., organic) food is not surprising ([1], p. 171). Change in food consumption practice in a sustainable direction is by no means an individual endeavor, but is only possible as part of the structural and social reorganizing of "systems of provision" [4,5]. Cultural meanings and norms have great impact on the propensity to change food consumption, both as an integral part of every given system of provision, but also through the enactment of individual consumer actions [6]. Supporting evidence for the latter can be found in how media coverage of environmental issues influences consumer environmental 
awareness and in the variation in organic food consumption due to cultural values and norms $[1,3]$. Given the slow pace of change in transforming food production and consumption practice in a sustainable direction, it is plausible that contemporary Western values and norms regarding food may be impeding the change needed. The difficulty of putting into practice a sustainable food provisioning system is illustrated by statistics on the market shares of organic and fair-trade food in European countries. The market for eco-labeled food is concentrated in Western Europe, Denmark, Switzerland and Austria, being the world's largest markets proportionally for organic food with $5 \%$ total market shares or more respectively [7,8]. In theory, eco-labeling is considered a primary tool for promoting sustainable consumption, as eco-labels both remind consumers of sustainable product alternatives and simultaneously provide trustworthy sustainable product alternatives, minimizing consumer time spent searching for sustainable products [9]. However, reviews of product-related environmental information show that eco-labels have limited impact on consumers outside the green segment [10,11]. These reviews suggest that even though information is provided in the marketplace to help consumers choose sustainable products, most consumers do not use it. In the case of food, this means that labeling schemes such as organic and fair-trade labels have limited impact on consumer demand for sustainably produced food [12]. Given the fact that large groups of consumers are neither familiar with, nor trust, sustainable food-labeling schemes and the fact that cultural meanings/values influence how consumers perceive sustainable food, there is a need to describe the meaning of sustainable food production for food consumers. In order for consumers to consider buying sustainably-produced food, they must recognize, understand and value the characteristics of such food. This article addresses the question of how sustainably produced food can be described in order to promote the consumption of such food. Literature in sustainable marketing is particularly useful when attempting to communicate the benefits of consuming sustainably-produced food. The aim of this article is to conceptualize the common denominators of sustainable production of six food products, drawing on recent literature in the fields of sustainable marketing literature.

The conceptualization of sustainable food production presented in this paper is based on empirical data concerning the sustainability-related consequences of six food products: pork (based on soy feed), farmed salmon (based on fish feed), rice, sugar, paprika (sweet peppers) and milk. This choice of food products reflects a focus on the production of sustainable food rather than on its distribution/consumption (i.e., prepared vs. unprocessed food). This focus on production is partly due to practical limitations, as the multitude of ingredients in prepared foods makes mapping their sustainability-related consequences difficult.

The concept of sustainable development embraces consumption- and production-related integrated consequences of food that are economic, social and environmental [13]. In this paper, sustainability-related consequences of food production are described as environmental, economic and socio-cultural. In the case of economic consequences, only indirect effects are described, i.e. economic effects not directly related to the financial transaction of selling/buying food. Thus, the price of food, however important for sustainable food provisioning, is not included as an economic consequence of food production, but rather its effect in terms of poverty and hunger, two issues that are related to the socio-cultural and environmental aspects of food production.

The article is structured as follows: In the first part, the literature relevant to the promotion of sustainable food consumption and production is reviewed. The second part deals with methodology, a 
discussion on the criteria for choosing cases, cases are presented, considerations in data collection are explained and the validity of the suggested conceptualization is discussed. Results describing casespecific, sustainability-related consequences and concepts capturing the common solution-oriented denominators of sustainable production of six food products are presented in the third part. In the concluding section, the contributions of this study are discussed and implications for future research suggested.

\section{Promoting Sustainable Food Consumption}

The promotion of sustainable consumption practice has attracted research interest from various disciplines with accordingly different focuses in terms of how to study and possibly change, unsustainable consumption practice. In the field of environmental psychology, pro-environmental beliefs and their relationship to behavior are emphasized [14,15]. Results indicate that characteristics for consumers who engage in sustainable consumption practice are problem awareness, environmental values and adherence to social and personal norms supportive of sustainable consumption [16-19]. In the case of food consumption, problem awareness results in consumer awareness of the links between consumption practices, for example, cooking and climate change. Hence they are more likely to eat less meat. Strong habitual consumer practices, such as eating meat, might be overcome if consumers assign value to the environment [16]. From a behavioral change perspective, the main difference between consumers who buy eco-labeled products or engage in sustainable consumer practice and those who do not, is how they value the environment. Consumers must, without any doubt, perceive the relationship between what they consume and effects on the environment in order to activate relevant environmental values. Consumer practices supported by social norms are more likely to be accepted than those unsupported by such social "pressure" [19,20].

In the field of consumer policy, communicative instruments such as product labeling schemes (third-party certified and other), consumer education campaigns, advisory schemes and consumer information are used to promote sustainable food consumption [21].

Consumer policy communicative instruments designed for this purpose use information and social norms to effect change [21]. Examples of communicative instruments supporting the demand for sustainable food are the labeling of organic and fairly-traded food, climate labeling and consumer education/information campaigns initiated by government and/or business on product-related sustainability issues. Communicative instruments aim to appeal to consumers' sense of responsibility [22]. Using motivational psychology, it has been suggested that education about sustainability issues related to consumer lifestyle is a way to empower consumers [3]. The implications for consumer policy in promoting sustainable food consumption led to various measures aimed at empowering individual consumers. Drawing on self-determination theory, education on sustainability problems connected to food consumption practices and on the possibility of overcoming these problems by changing one's behavior is suggested as an important consumer policy instrument [23]. Studies focusing on the promotion of sustainable consumption within environmental psychology and consumer policy are problematic for two main reasons. First, they rely on an information transmission model of communication assuming "that effectiveness (in labeling schemes, in consumer education campaigns) is embodied in information/knowledge (which, author insertion) rest on the idea that it can transfer 
from person to person and time-space to time-space without interrogation and interpretation" ([24], p. 38). In philosophical and methodological opposition to this view on information-as-a-thing, information-as-meaning represents a view on communication as the result of interpretation and dialogue [25-27]. To see consumers as creators of meaning imply that information-based efforts designed to change food consumption in a sustainable direction-must facilitate the sense-making or understanding of sustainable food [25]. This conception of communication is closely connected to the concept of verstehen (understanding) as our being in the world, a world where communication and knowledge is inherently social [25,27-29]. Two main implications for communication promoting sustainable food consumption follow the information-as-meaning view on communication. Body, mind and soul are parts of human sense-making/understanding [24]. Thus emotions are an integral part of all human knowledge and information efforts to promote sustainable food must not only be factual but also relate to consumer emotions. In addition, the social construction of meaning/knowledge implies that all communication is a means to an end, produced by actors to achieve certain goals [27,28]. Accordingly, information-based promotion of sustainable food consumption should aim to reflect a diversity of perspectives.

Secondly, literature provides plentiful evidence that merely informing consumers about alternative consumption alternatives is not enough to achieve behavioral change [11,30]. Within the field of consumer policy the relationship between individual consumption practice and cultural meanings is discussed in terms of altering structural conditions to make individual sustainable consumption practice "cheaper or more convenient or making undesired behavior more expensive or inconvenient" ([3], p. 164). In practice theory the material, social and time-spatial dependency of individual consumption is characterized as path dependency [30-32]. Hence change in individual consumption practice is not only a question of re-framing structures (financial and other) or norms that impede on sustainable consumption practice. Path dependency circumscribes change in individual practice as the experience, engagement in and accessibility to combinations of everyday practice limit the recruitment of individuals to practices [31]. Hence, efforts taken to promote sustainable food consumption should be viewed from a perspective that involves a bundle of interrelated everyday consumer practices.

One way to design information with the aim of promoting sustainable food consumption is to emphasize the specific features and benefits associated with sustainably produced food in an understandable and transparent way [2]. Recent literature in the field of sustainable marketing provides guidance on how to increase consumer knowledge and help change consumption-related norms. The key characteristic of sustainable marketing and branding is its dual communication focus on both product/service-related benefits and product/service-related solutions to sustainability-related problems [33-35]. Sustainable marketing, or the "new green marketing paradigm" emphasizes the educational and empowering requirements of marketing communication [34]. This empowering aspect of sustainable marketing communication implies that "marketing efforts may also require efforts to inform consumers about issues on the sustainability agenda and how they relate to lifestyles and choices" ([35], p. 180). Such educational marketing communication efforts enhance the possibility of engaging consumers in ways experienced as meaningful, which will create demand for brands that provide sustainability-related solutions [33,34]. Sustainable marketing thus moves beyond the information-as-a-thing communication model and shares traits with communicative information that acknowledge communication as negotiating meaning and exploring difference [27]. Truly empowering 
information, assuring diversity in perspectives reflecting different stakeholder positions on sustainable food, is based on dialogical interaction [26].

Dialogical communication is considered a main precondition for sustainable business practice [26]. In line with this, the successful marketing of sustainably produced food provides consumers with information about sustainability issues related to food production from different stakeholder positions including producers of food and the natural environment [36]. Such information, in order to release the thinking potential and diversity of perspective that is characteristic of the information-as-meaning communication model, must be communicated in such a way as to welcome both agreements and disagreements [24]. This means that the empowering of food consumers, in terms of the possibility of making a difference by consuming sustainably produced food, concerns primarily the process of communication. Our inability, as consumers or laypeople, to perceive the direct effect of global warming or toxic substances in water or soil inevitably makes the marketing of sustainably produced food difficult and complex in terms of credibility. If consumers cannot directly perceive the difference between sustainably and conventionally produced food, they must, in order to start buying sustainably produced food, ultimately value information on these issues. From a commodity discourse perspective, this means that marketers as cultural producers to a large extent prescribe how food is valued by consumers [37-40]. Change in the consumption of food in a sustainable direction can be achieved by describing food production from a variety of perspectives in a way that enables consumers to value the sustainability of food production.

\section{Defining Sustainable Food Production}

As no common and accepted definition of sustainable food production exists, sustainable food production is often related to the three pillars of sustainable development, namely: social, environmental and economical sustainable development $[2,41]$. More recently, cultural diversity has been accepted as the fourth pillar of sustainability [42]. Based on these four pillars of sustainability, the concept of sustainably produced food becomes complex and blurred and it is difficult to see how a) consumer understanding of such food would deepen, and b) sustainably produced food could be promoted, based on this conceptual framework. The American Public Health Association interprets sustainable development in terms of food production and defines a sustainable food production system (SFPS) as “...one that provides healthy food to meet current food needs while maintaining healthy ecosystems that can also provide food for generations to come with minimal negative impact on the environment. A sustainable food system also encourages local production and distribution infrastructures and makes nutritious food available, accessible and affordable to all" [43]. This definition does not provide consumers with the ability to distinguish between sustainably and non-sustainably produced food. The notion of sustainable nutrition can be used to sum up some of the most important aspects of sustainable food production [44]. Sustainable nutrition relates to food that is: enjoyable and easily digestible, plant-based, minimally processed, organically produced, regional and seasonal, fairly traded and packed in an environmentally-sound manner. The concept of sustainable nutrition is without doubt easier to understand, from a consumer perspective, than are the four pillars of sustainability. However, neither the conceptual relationship between sustainable development and food, nor the relationship between sustainable nutrition and food, provide guidance to consumers when choosing among options 
in the supermarket setting. From a sustainable agriculture perspective sustainable food production entails the recycling of soil nutrients in farming [45]. Educating consumers about basic food production principles in terms of the circulation of energy and nutrients at the farm level would, at least in theory, facilitate conscious consumer choice of sustainably produced food [46]. Considering the long distance, physically and mentally, between the production and consumption of food in the global food system, at least from a Western perspective, this strategy of food consumer empowerment is deemed ineffective at this time.

Literature within the field of food production and sustainable development was reviewed as a first step to address the gap in literature concerning information about sustainable food production that can be used when communicating with consumers about sustainability issues in food production.

\section{Food Production and Sustainable Development}

Food and sustainable development is a vast scientific area. Literature relevant for information on sustainable food production with the aim of communication about and promoting such food, focuses on the relationship between dominant food production practices, environmental sustainability and access to food on a global scale. These relationships uncover the diversity in perspectives (regarding sustainable food production) characteristic of dialogical (market) communication [26]. Four of the eight Millennium Development Goals are related to food production and consumption: to eradicate extreme poverty and hunger, to promote gender equality and empower women, to reduce child mortality and to ensure environmental sustainability [47]. The possibility of achieving the Millennium Goals is clearly intertwined with agricultural practice and the structure of the global food industry, which in turn reflect global food consumption patterns [48]. In 2010, approximately 925 million people were hungry/malnourished and the Food and Agriculture Organization of the United Nations (FAO) emphasizes the link between reducing hunger and sustainable agricultural practice in developing countries [49]. The right to adequate food for all people is stated in the FAO's voluntary guidelines [50]. Food security describes a situation in which all people always have "physical, social and economic access to sufficient, safe and nutritious food that meets their dietary needs and food preferences for an active and healthy life" [51]. Global agricultural and food provision systems have largely changed agricultural practices in developing countries in the direction of large-scale monocultures, undermining food security as subsistence farming, i.e., local small-scale farming based on traditional agricultural knowledge, has been replaced [52-54]. The global and industrialized food provision system negatively affects food security and increases poverty in a developing country context [55-57].

Dominant global food production practices share a number of characteristics that have adverse environmental effects. The intensive use of pesticides and chemical fertilizers, characteristic of industrial and monocultural food production, has reduced biodiversity in terms of soil fertility and the number of plant and animal species in agricultural landscapes $[55,58,59]$. This development has been spurred by the use of genetically engineered (GE) crops, where the intensified use of Roundup has increased the risk of weed pesticide resistance and changed the soil flora [60]. Ecosystem degradation must be reversed in order to feed the increasing number of inhabitants in the world [61-63]. The eight Millennium Development Goals set targets for the reduction of greenhouse gas (GHG) emissions, the reduction of biodiversity loss and increased water security. The role of agriculture and food production 
in achieving these targets is important [48]. Future food production will depend on the availability of water [58]. To feed the most hungry, the local availability of water must increase by $100 \%$ [63].

Environmental problems associated with dominant food production practices are intimately linked to poverty and food security. A review of the literature on dominant food production practices, environmental sustainability and access to food on a global scale result in an intrinsic web of sustainability-related consequences of food production. These consequences, often negative and interconnected, are illustrated in Figure 1. Animal welfare issues are placed under environmental consequences; connections between consequences are marked with arrows. Literature on sustainable food production, relevant for the communication and promotion of such food, is concerned with the interconnections between environmental consequences of food production, the indirect economic consequences of poverty and hunger as well as socio-cultural consequences as health. The interface between the economic, environmental and socio-cultural consequences in Figure 1 has guided the literature presented in this section. The relationship between food security and bio- as well as cultural diversity and the ones between sustainable food production and human health/animal welfare represent areas in literature that deal with these interfaces and interconnections.

Figure 1. Aspects of food production related to sustainable development including animal welfare.

$\underline{\text { Environmental consequences }} \quad$ Economic consequences

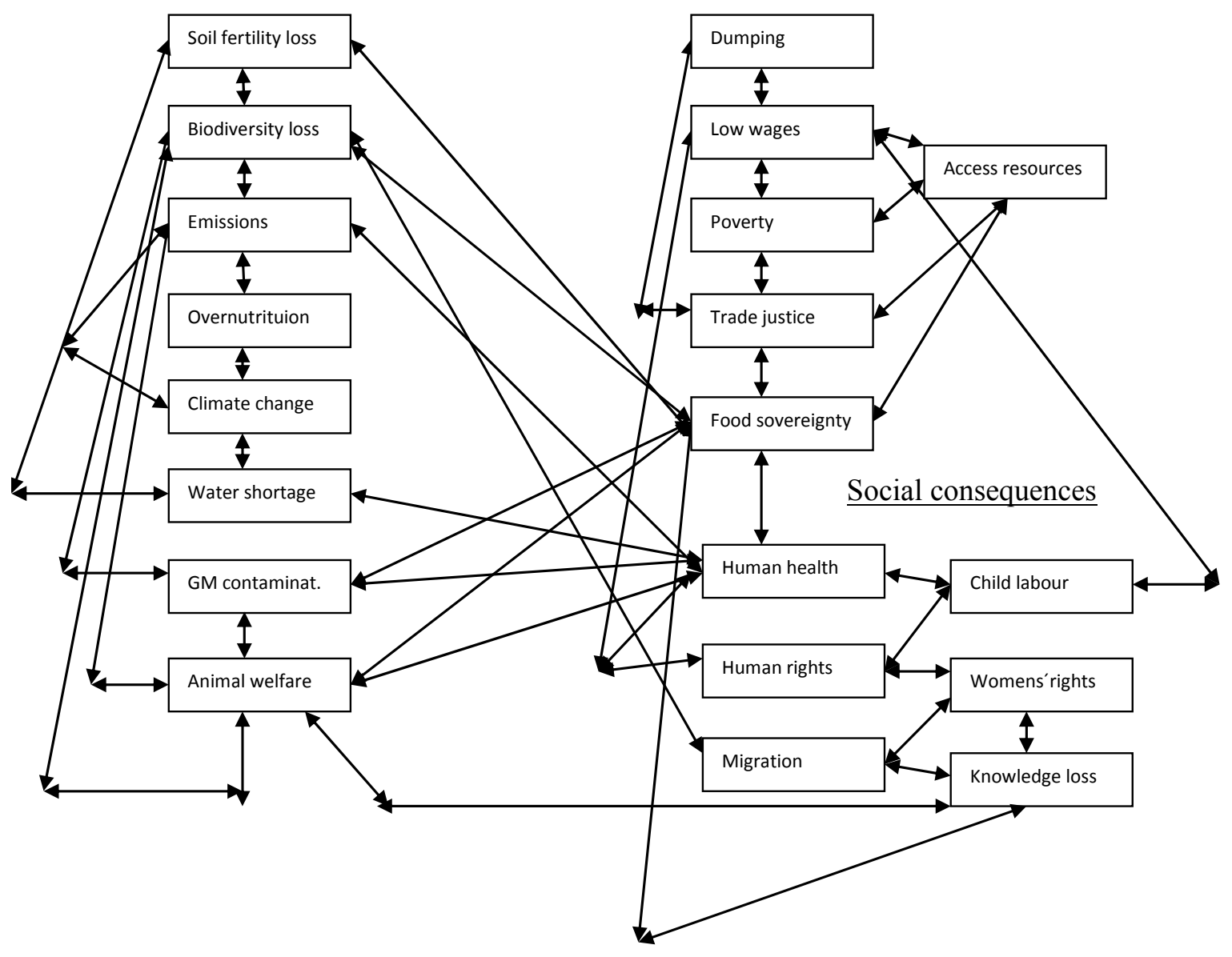




\subsection{Food Security as Bio-Cultural Diversity}

Cultural diversity as the fourth pillar of sustainability (as opposed to a global agri-industrial model of food production) indicates that locally-adapted food-production practices based on indigenous knowledge are effective in reducing hunger and poverty in developing countries [42,64-66]. Culturally diverse, locally-based farming practices, based on biological diversity, in terms of plant and animal species and ecosystems, enhance the resilience of small-scale farming in developing countries $[55,67,68]$. Resilience captures the ability of the environment and local communities to withstand and cope with change and stress, such as harsh conditions, drought and disease [45,67,69].

The bio-cultural diversity concept, linking diversity in the cultural sphere to diversity in plants, animals and ecosystems, is also applicable in a developed country context. Western industrial farming has been demonstrated to impede rural development in terms of employment, knowledge and income at the regional level [46,69]. Organic agriculture, as represented by small-scale poly-crop and biodiverse farms, has been recognized as a culturally diverse farming practice that improves food security and accessibility both in the North and South [64,66,70]. Organic agricultural yields exceed conventional yields in a developing country context characterized by low inputs of water and fertilizers and, if properly developed, can equal the yields of conventional farming in developed countries [70,71]. By building robust soils, organic agriculture sequesters carbon, which can help mitigate extreme weather conditions associated with climate change [66,72]. These advantages of organic agriculture are based on farming systems "imitating whole natural systems" in terms of the circulation of energy and nutrients [46]. Large-scale export-oriented organic food production, based on monocropping, is less advantageous as it neither provides food sovereignty/security nor is designed to circulate energy and nutrients, but is dependent on inputs such as fertilizers and animal feed [46,55,65,70]. Small-scale vs. large-scale organic farming is described as an inherent conflict between authentic organic and pseudo-organic systems. Authentic organic farming comprises small-scale biodiverse family farms producing food for subsistence and for the local market. Pseudo-organic farming is a large-scale, monoculture-based farming practice producing food for the global market without any clear link to food security and employment [67].

\subsection{Sustainable Food Production and Human Health}

Health effects related to current food production practice is related to what we eat and how food is produced. The major threats to human health related to the current Western food production system are related to the high-intake of meat and to pesticide use. The daily recommended daily meat intake is 50-100 g per person, whereas the average intake in high-income countries is 200-300 g [73]. Heart conditions, diabetes, obesity and colorectal cancer are some health disorders associated with a high intake of meat $[73,74]$. The transformation of the high-income diet to a less meat-based and more plant-based one, as called for by lowering of GHG emission targets, has positive consequences for human health. Pesticide residues in food are problematic for human health. The long-term health effects of consuming a combination of chemicals have not been studied extensively. However, research results suggest that a combination of pesticides might increase the toxicity of one given pesticide by up to ten times [75]. This makes small children particularly sensitive to "cocktails" of 
pesticides. As an example, maternal exposure to a cocktail of endocrine-disrupting chemicals causes alterations in the fetus neurodocrine system which is linked to reproductive health [76]. Additional health effects derive from the extensive use of pesticides in the agricultural sector. Health risks connected with the use of pesticides are linked to chemical residues on food, farmer exposure while spraying and indirect contamination of water and land. Farmer exposure to pesticides in developing countries is particularly alarming [59,77]. The extensive and multiple uses of food additives are also considered a major health risk to food consumers, particularly in the case of processed food [78].

\subsection{Animal Welfare and Sustainable Food Production}

The consequences of intensive animal husbandry for animal welfare and health are yet another aspect of sustainable food production. Livestock production is responsible for $18 \%$ of all global GHG emissions [74]. In conventional, highly intensive livestock production, animal health and welfare are often compromised [79-81]. Examples of the compromising of animal welfare include selective breeding, resulting in broiler chickens whose legs grow too fast and cripple them, the confinement of calves for veal production and breeding sows kept in crates on concrete floors or on straw, often nose-ringed to prevent their instinctive nest-building and rooting behavior [79,80,82]. The loss of pig genetic diversity due to selection for high output has resulted in less resistance to disease and reduced vitality [83]. Rawles proposes adapting the triangle of sustainable development (we presuppose that cultural diversity is included in the social pillar of sustainability) to a diamond in which animal welfare is included as an equally important element [84]. She argues that as the concept of sustainable development is ethically aspirational, "billions of sentient beings" cannot be overlooked but must be included.

\subsection{Interconnections between the Economic, Environmental and Socio-Cultural Consequences of} Food Production Summarized

The literature review both implicitly and explicitly identifies several conflicting ideas on how to feed the growing population of this planet. Clearly, it is beyond the scope of this article to do justice to all these controversies. From a consumer perspective, however, the most obvious dividing line in food production practice described in the literature is between large-scale industrial food production, dependent on inputs of energy, and nutrients and small-scale local-regional/subsistence food production in which nutrients and energy circulate at the local/farm level [52]. Depending on how food is understood and normalized, as globally-sourced and non-seasonal (following the large-scale industrial food production logic) or as locally-produced and seasonal (following a small-scale food production logic), consumers will make different food choices (not excluding the fact that change in consumer practice is culturally and structurally embedded). Another dividing line, relevant from a consumer choice perspective, is found in the perception of meat production. The industrial livestock production structure providing contemporary Western supermarkets with meat is based on a view of animals that accepts compromising their welfare [79,80]. Ethical arguments and animal rights propose another production paradigm that would imply higher prices and, plausibly, diets containing less meat [84].

As a second step in addressing the gap in literature concerning information about sustainable food production that can be used when communicating with consumers, an empirical investigation of 
sustainability-related consequences linked to the production of six food products was undertaken in order to conceptualize the common solution-oriented denominators of sustainable food production.

\section{Methodology}

The conceptualization of sustainable food production presented here is based on empirical data on sustainability-related consequences linked to the production of six food products: pork based on soy feed, farmed salmon based on fish feed, rice, sugar, paprika (sweet peppers) and milk. Methodologically, these foods represent six cases in an extensive multiple case study [85]. Case selection followed a critical case sampling method in which the author selected the foods regarded as most relevant to how various types of consequences (e.g., environmental, economic and social) are interconnected [86]. The number of selected cases follows Eisenhardt's suggestion [87].

\subsection{The Cases}

Based on the web of sustainability-related consequences of food production illustrated in Figure 1, the main criterion for including a food in this study was the ability of its production to illustrate how various types of consequences (e.g., environmental, economic and socio-cultural) are interconnected. Concepts describing sustainable food production valid outside the specific cases, i.e., concepts capturing the common solution-oriented denominators of food production that is economically, ecologically, socially and culturally sustainable, must be based on a maximum variation in terms of how food production is connected to environmental, economic, social and cultural consequences. Food products were selected with the aim of covering all consequences and as many interconnections between consequences as possible, as illustrated in Table 1. Thus the selected food products/cases, which are described below, represent:

a. Food chains that are local, regional and global

b. Differing environmental, social and cultural impacts

c. Protein/non-protein foodstuffs from animals and fish

Table 1. Selected food products in relation to market, impacts, protein from animal/fish and geographic perspective.

\begin{tabular}{|c|c|c|c|c|}
\hline & Food chain & Environmental and social impact & Protein & $\begin{array}{l}\text { Geographic } \\
\text { perspective }\end{array}$ \\
\hline Rice & regional-global & Dumping, hunger, "improved" seeds/pesticide use $[45,88]$. & no & Indian \\
\hline Pork/soy & global & All consequences illustrated in Figure $1[52,53,89]$ & yes & Dutch \\
\hline $\begin{array}{l}\text { Salmon/ } \\
\text { fish }\end{array}$ & global & $\begin{array}{l}\text { Biodiversity, the welfare of wild fish, human health and } \\
\text { employment }[90,91] \text {. }\end{array}$ & yes & Norwegian \\
\hline Sugar & regional-global & Price volatility social/economic consequences. Child labor $[56,92]$. & no & Brazilian \\
\hline $\begin{array}{l}\text { Sweet } \\
\text { Pepper }\end{array}$ & local-regional & $\begin{array}{l}\text { Heavy pesticides use, environmental consequences at farm and risk } \\
\text { for human health [59]. }\end{array}$ & no & Dutch \\
\hline Milk & local-regional & Animal welfare, rural development, biodiversity [93]. & yes & Swedish \\
\hline
\end{tabular}


Due to both financial reasons and access to secondary data, cases have a clear geographical perspective, and are described in Table 1 below. Having a geographical perspective does not imply reducing food production to the characteristics of a given geographic area. Instead, it means that a certain geographic focus, by means of contacts with research and/or research institutes situated in the area, has guided the initial collection of data on sustainable related consequences of food production.

\subsubsection{Sugar}

The production of sugar has been studied from a Brazilian perspective. Brazil is, in close competition with India, the world's largest producer of sugar [94]. Sugar can be made from sugarcane grown in the tropics or from sugar beet grown mainly in Europe and North America. The international sugar market is characterized by harsh competition and political struggles between sugarcane and sugar beet $[95,96]$. This competition is regarded as a struggle over the right to sugar income [95,96]. In similar fashion to prices of other primary, globally-traded commodities, sugar prices are volatile and falling. For short periods world sugar prices rise sharply, followed by long periods of much lower prices $[95,97]$. The Brazilian perspective highlights a number of interconnected, sustainability-related consequences of sugar production that are related to structural and politically-negotiated economic effects;

1. Historically, sugar has been produced from sugarcane, cultivated in large plantations in the tropics. Sugarcane plantations have been associated with poor labor conditions, low wages, health risks and environmental damage [97,98]. Sugar exports currently play an important role in the economies of many developing countries. Small-holder sugarcane production in LDCs (least developed countries) is regarded as a means to reduce poverty and advance sustainable development [95,98-100]. Sugar from cane is traded as raw or white sugar, whereas beet sugar is only traded as white [101].

2. Sugar beet-derived sugar accounts for one third of the world's sugar production [97]. Sugar beet cultivation occurs mainly in the EU and the USA. EU beet sugar accounts for $13 \%$ of the world market [101]. The cost of producing sugar from beets is higher than from cane; the EU sugar beet industry is protected by subsidies and prices are kept high by dumping on markets outside the EU and by import quotas $[95,96]$.

\subsubsection{Pork Based on Soy Feed}

In this project, pork based on soy feed was primarily studied from a Dutch perspective for two reasons:

1. The Netherlands and Belgium have more pigs per hectare than any other European country [102].

2. Dutch researchers are well represented in research into pig farming and sustainable pig supply chains.

The production of pork based on soy feed in many respects illustrates the globalization of food production. This production chain represents the agro-industrial model of food production in which exports and competition are the main cornerstones of every step of the value chain $[53,89]$. When describing the sustainable aspects of producing pork based on soy feed, these aspects are intertwined 
with food regimes in Western Europe. European meat consumption increased from 56 kilograms per person annually in 1960 to approximately 89 kilograms in 2000 [103]. In countries such as Brazil, China and Japan, meat consumption is increasing at even higher rates. The World Bank states that "global meat demand is expected to grow from 209 million tons in 1997 to 327 million tons in 2020 $(56 \%)$... It is anticipated that most of this increase will come from animals kept in intensive farms, the majority of them in the developing world." [103].

\subsubsection{Farmed Salmon Based on Fish Feed}

The production of farmed salmon was studied from a Norwegian perspective. Norway is, followed by Chile, Scotland and Canada, the world's largest producer of farmed salmon [90]. Aquaculture, i.e., the farming of fish or other aquatic organisms, accounts for approximately $50 \%$ of world fish production [104]. Salmon (Salmo salar) is one of two main fish species farmed in Europe. The production of farmed salmon has increased dramatically since early 1980, increasing 55-fold over the period 1983-2003 [105]. The development of fish farming in many respects parallels that of terrestrial livestock farming in terms of the increasing intensification and globalization of this food provisioning system [106]. Cold water farming of carnivorous salmon is an intensive monoculture fish farming system [106]. With its use of industrial feed and technologies aimed at increasing productivity, it represents the agri-industrial model of food provisioning [107].

\subsubsection{Rice}

Rice has been studied from an Indian perspective. For rice, two main agricultural production systems exist $[88,108-110]$.

1. An agro-industrial production system, monocrop based, focusing mainly on selling on the global market and depending on hybrid rice varieties and large chemical inputs in the form of fertilizers and pesticides. The intensive use of chemical fertilizers and pesticides is characteristic of the cultivation of "high-yielding" hybrid rice introduced during the Green Revolution in the 1970s [65,108]. "High yielding" is in fact an inaccurate descriptor; the main characteristic of hybrid rice varieties is that they are highly responsive to fertilizer and water inputs, so the correct descriptor would be "high-responsive" rice varieties [65].

2. A traditional food provision-based agricultural production system that is characterized by poly-cropping and local varieties of rice adapted to regional ecosystems [111]. This production system is characterized by use of biological pest control and fertilizers, biodiversity and little chemical dependence [65,112].

\subsubsection{Sweet Peppers}

Sweet pepper production was studied from a Dutch perspective. The Netherlands is the second largest European producer of sweet peppers and the 10th largest producer globally [113]. In Europe and in the USA, sweet peppers are cultivated in protected horticulture or open field production [114]. There are two main types of protected horticulture, glasshouse production, as in the Netherlands and Israel, and plastic-covered production, as in Spain and Florida [115-117]. There is a distinction 
between protected horticulture as an environmental necessity due to cold climate and as an integrated pest management (IPM) tactic initiated to control pests [118]. The consequences of sweet pepper cultivation are related to how the peppers are grown, whether in protected horticulture or on open land. In protected horticulture, peppers are grown on substrate made from Rockwool ${ }^{\circledR}$ or peat while in open fields peppers are grown in the soil. Sweet peppers can be grown organically in both production schemes $[119,120]$.

\subsubsection{Milk}

Milk has been studied from a Swedish perspective. The studied milk production is large scale, intensive and based on monoculture, in the sense that livestock farms specialize in cows or pigs [93,121]. Approximately $40 \%$ of Swedish farms have livestock-related production (e.g., meat, dairy, or egg production). Animal feed is cultivated on $70 \%$ of cultivated land in Sweden. This high degree of specialization in Swedish agriculture has a number of environmental, economic and social consequences.

\subsection{Data Collection}

Data on the environmental, indirect economic, social and cultural consequences of the selected food production systems, both conventional and organic, were gathered for each case in 2010. Case-specific literature reviews were undertaken, initially from a certain geographic perspective, for each case. The initial collection of secondary data on sustainable related consequences of food production was facilitated by contacts with research institutes in different geographic areas. In some cases these contacts were combined with field visits and expert interviews with researchers with competence in sustainable production of rice, sugar, soy/pork and sweet pepper. Field trips included visits to research centers in the field of sustainable agriculture and production sites, for organic sugar (Brazil), rice (India) and sweet peppers (Holland). The initial geographical focus on data collection was broadened to describe sustainability-related consequences of food production on a global scale. The procedure of collecting data on the consequences of food production for each case was continued until theoretical saturation was reached, i.e., until additional data on environmental, indirect economic and socio-cultural consequences of producing the selected food products did not add in any meaningful way to the categorization of these consequences [122,123].

\subsection{Analytical Procedure}

The conceptualization of sustainable food production presented in the results section was developed by first categorizing consequences for each case and second, by means of a cross-case analysis. The consequences related to the production of each of the six food products/cases are described and presented in an abbreviated form in Table 2 as the first analytical step. In the cross-case analysis, patterns were distinguished, in terms of hot-spots, by comparing similarities and differences across cases [87]. The cross-case analysis is summarized in Table 3. 
Table 2. Consequences related to the production of each of the six food products.

\begin{tabular}{|c|c|c|}
\hline Sugar & Sugar cane & Sugar beet \\
\hline $\begin{array}{l}\text { Environmental } \\
\text { consequences }\end{array}$ & $\begin{array}{l}\text { Soil degradation due to erosion, use of chemicals and cane burning [99,124]. } \\
\text { In organic sugar cane cultivation, soil vitality is improved through the non- } \\
\text { burning of cane. Remaining trash, combined with used organic compost, } \\
\text { increase soil quality and fertility [111]. } \\
\text { Water scarcity and degradation [98,99] due to chemical contamination of } \\
\text { water, irrigation and cleaning of sugar mills. Organic sugar production affects } \\
\text { water in two ways. Organic sugar cane cultivation consumes less water as } \\
\text { water is stored in the soil and water quality is improved as the increased } \\
\text { organic activity of the soil filters the water [126]. } \\
\text { Air pollution due to the burning of bagasse (fibrous waste produced in the } \\
\text { milling process) and burning of cane [99]. In organic cane production cane is } \\
\text { not burned. } \\
\text { Green house gas emissions due to heavy use of chemical fertilizers and } \\
\text { burning of cane [124,125]. In organic cane production biological pest control } \\
\text { is applied and organic fertilizers are used, reducing GHG emissions and cane } \\
\text { is not burned. } \\
\text { Habitat loss due to the clearing of forest and savannah for cane [99,127]. } \\
\text { [ } 99,128] \text {. Biodiversity restoration is an important dimension of organic sugar } \\
\text { cane cultivation [128]. }\end{array}$ & $\begin{array}{l}\text { Soil degradation due to erosion and chemical input }[98,99] \text {. } \\
\text { Water pollution through chemical contamination of water }[98,99] \text {. } \\
\text { Green house gas emissions due to heavy chemical use (fertilizers and } \\
\text { pesticides) [125]. Sugar beet production accounts for a considerably higher } \\
\text { amount of GHG emissions than is the case with sugar cane. } \\
\text { Biodiversity loss - due to chemical use }[98,99] \text {. }\end{array}$ \\
\hline
\end{tabular}


Table 2. Cont.

\begin{tabular}{|c|c|c|}
\hline Sugar & Sugar cane & Sugar beet \\
\hline $\begin{array}{l}\text { Economic } \\
\text { consequences }\end{array}$ & $\begin{array}{l}\text { Export earnings. Sugar cane exports play an important role in the economy of } \\
\text { many developing countries }[98,127] \text {. } \\
\text { Poverty as land formerly used for subsistence farming and the sale of surplus } \\
\text { products in local markets is replaced by monoculture. Small holder sugar cane } \\
\text { production in LCD: regarded as a means to reduce poverty and work with } \\
\text { sustainable development }[98-100] \text {. }\end{array}$ & $\begin{array}{l}\text { Export earnings. The EU and US (and Japanese) sugar market is effectively } \\
\text { protected by import restrictions. Income generated by the global sugar } \\
\text { industry is in part allocated to European sugar corporations [98,100]. } \\
\text { Subsidies. The sugar policy of the EU is based on considerable subsidies. } \\
\text { Thus high priced sugar in the EU is subsidized by European taxpayers [98]. }\end{array}$ \\
\hline & $\begin{array}{l}\text { Import quotas. Sugar producers outside the EU or the US have limited access } \\
\text { to these markets as they are protected by import restrictions }[98,100] \text {. } \\
\text { Dumping. Sugar made from beet is continuously dumped in overseas, often } \\
\text { poor, markets }[98,100] \text {. }\end{array}$ & Increased concentration in sugar export trade [92]. \\
\hline $\begin{array}{l}\text { Socio-cultural } \\
\text { consequences }\end{array}$ & $\begin{array}{l}\text { Poor working conditions. Child labor, bonded labor and extremely hard and } \\
\text { dangerous working conditions in sugar cane plantations }[99,124] \text {. } \\
\text { Land concentration. Large-scale sugar cane cultivation is linked to the } \\
\text { concentration of land [124,127] affecting areas for subsistence farming. } \\
\text { Agro biodiversity and food security. Large scale sugar cane plantations } \\
\text { threaten food security as less crops are cultivated for food and less livestock is } \\
\text { held [127]. }\end{array}$ & \\
\hline
\end{tabular}


Table 2. Cont

\begin{tabular}{|c|c|c|}
\hline $\begin{array}{l}\text { Pork based } \\
\text { on soy feed }\end{array}$ & Soy & Pig farming \\
\hline $\begin{array}{l}\text { Environmental } \\
\text { consequences }\end{array}$ & $\begin{array}{l}\text { Greenhouse gas emissions due to deforestation of tropical rainforest and the } \\
\text { savannah, the use of pesticides and fertilizers [128-131]. } \\
\text { Biodiversity loss. Soya production for feed constitutes a threat to biodiversity. } \\
\text { As such, a food provision structure leads to excessive levels of pesticides and } \\
\text { fertilizers as well as deforestation }[89,129,132] \text {. } \\
\text { Soil degradation due to erosion resulting from deforestation and a monoculture- } \\
\text { related loss in fertility [129,132]. In Argentina, the traditional pre-soy system of } \\
\text { rotating livestock with crop cultivation on a seasonal basis promoted the vitality } \\
\text { of the soil with organic compost and manure [132]. } \\
\text { Water degradation and scarcity due to deforestation, the use of chemical } \\
\text { pesticides and fertilizers and high water consumption are associated with high } \\
\text { response varieties monoculture agriculture [129,132]. } \\
\text { Increased vulnerability to disease and weeds due to resistance to agrochemicals } \\
\text { and related biosafety issues as herbicide-resistant genes move to wild plants. } \\
\text { This development is spurred by the use of GE crops, where an intensified use of } \\
\text { Round-up (glyphosate) increases the risk of resistance and change in the flora } \\
\text { [60,132,138]. }\end{array}$ & $\begin{array}{l}\text { Gas emission, greenhouse gases as methane and nitrous oxide and other } \\
\text { gases as ammonia [133]. Livestock production accounts in total for } 18 \% \text { of } \\
\text { global GHG emissions [73,134]. The leading source of livestock related } \\
\text { emissions originate in the biological processes of digestion and excretion. } \\
\text { Water scarcity. Producing meat is water-costly as one calorie of meat } \\
\text { consumes more water than one calorie of grain. This relatively large water } \\
\text { footprint of meat is due to the amounts of water required to grow livestock } \\
\text { feed [135,136]. } \\
\text { Leakage of nutrients as nitrogen and phosphorus [69,137,138] to highly } \\
\text { specialized and intensive live stock breeding. } \\
\text { Pollution of land and water. The volume of waste from livestock } \\
\text { populations causes contamination of land as ammonia emissions and surplus } \\
\text { of minerals [139]. } \\
\text { Genetic uniformity. Local breeds of domesticated pigs have been lost. } \\
\text { Breeding in the West, now exported to the South, aims at maximizing } \\
\text { productivity, including meat output [69]. This loss in genetic pig diversity } \\
\text { has resulted in less resilience and vitality due to selection for high output } \\
\text { [133]. One third of the pigs in the world are genetically very similar as they } \\
\text { come from industrial breeding lines [69]. The export of these breeds to } \\
\text { developing countries, where small-scale family farms adapted to the local } \\
\text { condition are crucial for food security, threatens food sovereignty. }\end{array}$ \\
\hline
\end{tabular}


Table 2. Cont.

\begin{tabular}{|c|c|c|}
\hline $\begin{array}{l}\text { Pork based } \\
\text { on soy feed }\end{array}$ & Soy & Pig farming \\
\hline \multirow[t]{2}{*}{$\begin{array}{l}\text { Economic } \\
\text { consequences }\end{array}$} & $\begin{array}{l}\text { Poverty. Small scale farmers lose land to large scale soy producers, land where } \\
\text { they used to grow food, or medicinal plants, for themselves. Agricultural } \\
\text { laborers have less work opportunities in highly mechanized soy cultivation and } \\
\text { the shortage of employment causes salaries to decrease }[129,132,140] \text {. Urban } \\
\text { migration is the result of the soy expansion related poverty and overcrowded } \\
\text { city slums offer few job opportunities. There is evidence that those already in } \\
\text { poverty have borne the worst economic impacts of soy expansion in Brazil and } \\
\text { Paraguay }[132,141] \text {. }\end{array}$ & $\begin{array}{l}\text { Income and employment on the regional level if, as in the De Hoeve case in } \\
\text { the Netherlands, pig farmers cooperate and create regional markets for their } \\
\text { products based on sustainable value [139]. } \\
\text { Consolidation of production in terms of intensive transnational pig meat } \\
\text { producing companies [139]. }\end{array}$ \\
\hline & $\begin{array}{l}\text { Unemployment. Small farmers without land and little employment } \\
\text { opportunities (soy farming without farmers) result in increased levels of } \\
\text { unemployment among those whose income and resources are already small } \\
{[129,140,141] \text {. }}\end{array}$ & \\
\hline $\begin{array}{l}\text { Socio-cultural } \\
\text { consequences }\end{array}$ & $\begin{array}{l}\text { Food security and food sovereignty. The replacement of small scale farming for } \\
\text { subsistence and the local market with large scale agro-industrial soy cultivation } \\
\text { is a major threat to food sovereignty and food security [129,130,132,140]. As } \\
\text { traditional pasture- and farmland is lost to soy in Argentina, production of } \\
\text { traditional crops has fallen and prices of vegetables, meat and milk have } \\
\text { increased [132]. Many Argentineans can no longer afford to eat meat and in the } \\
\text { case of milk, decreased production has resulted in expensive milk imports. } \\
\text { Hunger and malnutrition affects approx } 20 \% \text { of infants in Argentina [132]. }\end{array}$ & $\begin{array}{l}\text { Animal welfare. The industrial production of livestock farming has serious } \\
\text { animal welfare implications [80]. This agri-industrial farming model is } \\
\text { based on indoor farming and selective breeding [136].). Indoor farming } \\
\text { means that animals are deprived of fresh air and natural behavior. In their } \\
\text { natural conditions pig sows live together in small groups, greeting each } \\
\text { other by nose to nose contact and finding isolated and protected sites to give } \\
\text { birth. Piglets are weaned and stay with their mother for a minimum of } 17 \\
\text { weeks [82]. }\end{array}$ \\
\hline
\end{tabular}


Table 2. Cont

\begin{tabular}{|c|c|c|}
\hline $\begin{array}{l}\text { Pork based } \\
\text { on soy feed }\end{array}$ & Soy & Pig farming \\
\hline $\begin{array}{l}\text { Socio-cultural } \\
\text { consequences }\end{array}$ & $\begin{array}{l}\text { Health. The ever-increasing use of highly toxic pesticides has led to an } \\
\text { increasing number of cancer diagnoses in the Brazilian state of Mato Grosso } \\
{[130] \text {. In Paraguay the great majority of families investigated in four }} \\
\text { departments of the country reported health problems caused by pesticide } \\
\text { spraying and contaminated water. } \\
\text { Migration. Landless farmers and unemployed agricultural workers move to } \\
\text { the slums of big cities where few jobs for the uneducated are to be found } \\
{[129,132] \text {. It has been estimated that in Paraguay approx. 90,000 small }} \\
\text { farmers have abandoned their land since } 1990 \text { because of soy expansion } \\
{[140] \text {. }} \\
\text { Social unrest. Increased pressures on land for soy production causes land } \\
\text { conflicts, evictions, criminalization and violence [129,132]. } \\
\text { Loss of cultural diversity. Indigenous peoples right to land and the possibility } \\
\text { to live on and from their land is threatened by deforestation and the chemical } \\
\text { contamination of water. Indebtedness and the selling of land among small } \\
\text { scale farmers disrupt rural agricultural communities [132,140]. This rupture } \\
\text { of local rural communities undermines traditional agricultural knowledge, } \\
\text { linked to local conditions and fauna, as for example polycropping, biological } \\
\text { pest control and plants used as medicine [140]. } \\
\text { Debt peonage. Slave-like working conditions exist in some states in Brazil, } \\
\text { where workers are in debt because of housing, food or equipment which } \\
\text { makes it impossible for them to leave farms or plantations [130]. }\end{array}$ & $\begin{array}{l}\text { In industrial indoor farming, piglets are separated from their mother after 2-4 } \\
\text { weeks and housed together. Routine mutilations, including castration, } \\
\text { tail-docking and tooth clipping are part of this farming system [89]. Pigs are } \\
\text { kept on concrete or on straw. Breeding sows are kept in crates on concrete } \\
\text { floor or on straw, often nose-ringed to prevent them from rooting as a part of } \\
\text { their nest-building behavior [80, 89]. } \\
\text { Selective breeding, aiming at maximizing the output of meat, milk and eggs, } \\
\text { causes excessive and unnatural growth that results in health problems such as } \\
\text { heart weakness, deformities of the legs and poor immune systems that make } \\
\text { the animals sensitive to bacteria and disease [73,82,142]. } \\
\text { Spreading of infectious disease and drug-resistant bacteria to humans. } \\
\text { Approximately three quarters of the scientifically-confirmed resurgence of } \\
\text { emerging infectious human diseases are linked to the expansion and } \\
\text { industrialization of meat farming [143,144]. Intensive confinement linked to } \\
\text { high stocking densities which allow no possibility for animals to move } \\
\text { according to their instincts, no sunlight, stress-induced tail biting and the poor } \\
\text { hygienic practices of castration, tail-docking and tooth-cutting are some } \\
\text { examples of factors that suppress the immune system of farmed pigs and } \\
\text { make them susceptible to disease [145]. The } 2005 \text { outbreak of Streptococcus } \\
\text { suis in Chinese industrial pig farms is an example of how virulent strains of } \\
\text { disease are intimately related to intensive meat farming [146]. Sprep. suis is } \\
\text { now a common source of meningitis in farmed pig worldwide and in people } \\
\text { [147]. Multidrug-resistant bacteria, causing antibiotic resistant human disease, } \\
\text { are linked to the use of antibiotics in industrial meat farming [148,149]. } \\
\text { Rural development. Industrial pig meat production in Netherlands (and } \\
\text { elsewhere) is primarily situated in industrial clusters disconnected from rural } \\
\text { areas. [89,139]. Pig farmers are exchangeable; pig farming is, as a profession } \\
\text { and as an agricultural practice, no longer part of the Dutch rural society and } \\
\text { landscape [139]. Industrial pig farming impedes rural development, including } \\
\text { employment, knowledge and income, at the regional level [139]. }\end{array}$ \\
\hline
\end{tabular}


Table 2. Cont.

\begin{tabular}{|c|c|c|}
\hline $\begin{array}{l}\text { Farmed salmon } \\
\text { based on fish feed }\end{array}$ & Fishmeal & Salmon farming \\
\hline $\begin{array}{l}\text { Environmental } \\
\text { consequences }\end{array}$ & $\begin{array}{l}\text { Reduced aquatic biodiversity due to depletion of wild fish stocks used for fish } \\
\text { feed [106]. Many effects from overfishing wild stocks used for fish feed are } \\
\text { indirect, over-exploitation of fish for feed leads to the decline of other wild } \\
\text { fish, such as cod, as there is more competition for food [106]. }\end{array}$ & $\begin{array}{l}\text { Reduced aquatic biodiversity due to chemical residues, the release of organic } \\
\text { matter into water and falling numbers of wild salmon as a result of farmed fish } \\
\text { causing competition for feed and habitat, transfers of infections and parasites and } \\
\text { genetically-dubious interbreeding [90,106,150]. In addition salmon farms are } \\
\text { highly attractive to predators, such as otters, seals, sea lions, fish eating birds and } \\
\text { mink. These animals are killed to ensure the productivity of fish farms [150]. In } \\
\text { organic salmon farms measures are taken to restore biodiversity. } \\
\text { Habitat degradation as a result of pollution from fish waste, excess feed and } \\
\text { chemicals. This waste affects the seabed at a considerable distance from fish } \\
\text { farms and for long periods of time. Sediment caused by waste releases } \\
\text { compounds, such as phosphates and methane, into the water, which can } \\
\text { predispose sea beds to toxic algal blooms [150]. }\end{array}$ \\
\hline $\begin{array}{l}\text { Economic } \\
\text { consequences }\end{array}$ & $\begin{array}{l}\text { Decreasing income and employment in fisheries in developing countries as } \\
\text { wild fish stocks used for feed are decreasing }[152,153] \text {. Future economic } \\
\text { drawbacks for smallholder subsistence/local market fishing are to be expected } \\
\text { as over-exploitation due to fish feed has effects on all kinds of wild fish } \\
\text { stocks. }\end{array}$ & $\begin{array}{l}\text { Decreasing employment and less qualified/paid jobs due to mechanization in } \\
\text { salmon farming [151]. } \\
\text { Concentration of global trade [154]. }\end{array}$ \\
\hline
\end{tabular}


Table 2. Cont

\begin{tabular}{|c|c|c|}
\hline $\begin{array}{l}\text { Farmed salmon } \\
\text { based on fish feed }\end{array}$ & Fishmeal & Salmon farming \\
\hline $\begin{array}{l}\text { Socio-cultural } \\
\text { consequences }\end{array}$ & $\begin{array}{l}\text { Food or feed. As farmed salmon is based on feed using wild caught fish a } \\
\text { competitive situation for protein between humans and farmed fish will occur } \\
\text { in the future [106]. }\end{array}$ & $\begin{array}{l}\text { Fish health and welfare is threatened is intensive salmon farming. The high } \\
\text { stocking density of salmon in cages is the main cause of several interrelated } \\
\text { health and welfare problems [90,150]. Another major source for welfare- and } \\
\text { health-related problems in farmed salmon are breeding methods based on } \\
\text { biotechnology and genetic engineering aiming for fast fish growth [90]. Some of } \\
\text { the most serious threats to fish health and welfare are: (1) stress and aggression } \\
\text { caused by constraints in natural swimming, living and feeding behavior, (2) } \\
\text { increased susceptibility to disease and parasites, (3) increased levels of physical } \\
\text { injuries, (4) reduced growth and feed intake, (5) increased mortality, ( } \& \text { ) } \\
\text { unethical slaughtering methods [90,150]. Organic farms are semi-intensive as the } \\
\text { stocking density is reduced. } \\
\text { Genetic uniformity. Farmed salmon is based on a few breeding lines to maximize } \\
\text { growth and fish meat output. Farmed salmon have a reduced body streamline } \\
\text { profile, shorter fins, reduced swimming performance and different heart } \\
\text { configurations which are disadvantageous in the wild condition [69]. As farmed } \\
\text { salmon often escape and interbreed with wild salmon, these genetic uniformities } \\
\text { have detrimental consequences for the wild population. [155]. } \\
\text { Fish provisioning as separated from rural community development. The large } \\
\text { scale and intensive farmed salmon industry is operated by a few global } \\
\text { companies. This aqua-industrial fish production system is disconnected from } \\
\text { development, employment and income in rural coastal communities } \\
\text { [106,107,151]. } \\
\text { Human health consequences are caused by artificial coloring, antibiotics, the } \\
\text { fungicide malachite green (increasing the risk for cancer and harmful to the } \\
\text { human reproductive system), as well as contaminants like dioxin in feed [156]. } \\
\text { negative consequences as inadequate protection of workers, low wages, no } \\
\text { employment contracts, no insurance schemes and no trade union schemes [151]. }\end{array}$ \\
\hline
\end{tabular}


Table 2. Cont

\begin{tabular}{|c|c|c|}
\hline Rice & Agro-industrial production & Food-provision based production \\
\hline $\begin{array}{l}\text { Environmental } \\
\text { consequences }\end{array}$ & $\begin{array}{l}\text { Soil degradation, erosion and salinization }[89,109,112] \text {. } \\
\text { Water scarcity and degradation through contamination of water and overuse of } \\
\text { water }[88,108,110,157] \text {. } \\
\text { Green house gas emissions due to heavy chemical use and methane emissions } \\
\text { from wetland rice fields [157-159]. } \\
\text { Biodiversity loss-due to chemical use, small seed base and biopollution } \\
\text { [65,88,160]. } \\
\text { Increased vulnerability to disease and weeds due to resistance to } \\
\text { agrochemicals and related biosafety issues as herbicide-resistant genes move } \\
\text { to wild plants and create so called super-pests, as well as creating "super pests } \\
\text { by killing predators and contributing to the emergence of pest-resistance" } \\
\text { [88,161,162]. }\end{array}$ & $\begin{array}{l}\text { Soil vitality and moisture due to use of organic matter and "organic principles } \\
\text { of root development" }[88,109,112,157] \text {. } \\
\text { Biodiversity in seed (locally-bred varieties adapted to local conditions), flora } \\
\text { and fauna }[65,88] \text {. } \\
\text { Reduced green house gas emissions due to chemical use [157]. Methane } \\
\text { emissions from wetland rice fields }[158,159] \text {. }\end{array}$ \\
\hline $\begin{array}{l}\text { Economic } \\
\text { consequences }\end{array}$ & $\begin{array}{l}\text { Debt. Farmers' investments in seeds (terminator seeds producing a rice plant } \\
\text { with no breeding ability and chemical inputs must be covered by the crop } \\
\text { harvested }[163] \text {. When the crop is smaller than expected farmers are left in } \\
\text { debt }[88,110] \text {. } \\
\text { Risk. The monoculture associated with hybrid rice production means that } \\
\text { complementary harvests normally used for food and surplus, and sold in local } \\
\text { markets, thus alleviating risk, are lost }[88,160] \text {. }\end{array}$ & $\begin{array}{l}\text { Increasing long-term yields. Compared to the agro-industrial rice production } \\
\text { system, the rice yields of traditional food-provision rice farming are equal in } \\
\text { the short-term but higher over the longer term as agro-industrial rice } \\
\text { production historically declines over time }[88,164] \text {. } \\
\text { Risk reduction. As a secondary effect of the poly-crop based farming system, } \\
\text { farmers spread their economic risks by being able to sell more than one crop } \\
\text { on the local market. }\end{array}$ \\
\hline
\end{tabular}


Table 2. Cont.

\begin{tabular}{|c|c|c|}
\hline Rice & Agro-industrial production & Food-provision based production \\
\hline $\begin{array}{l}\text { Socio-cultural } \\
\text { consequences }\end{array}$ & $\begin{array}{l}\text { Land-grab. Agro-industrial production of rice represents a type of monocrop } \\
\text { food provision system that has recently been connected to land-grab } \\
{[162,163] \text {. The economic consequences for a country that leases large parts of }} \\
\text { agricultural land to foreign investors/countries might be positive in the short- } \\
\text { term and for small groups of the population. In the long-term, land-grabbing } \\
\text { pushes poor rural farmers from their land, increasing food security and food } \\
\text { sovereignty, causing poverty and potential conflicts over water. } \\
\text { Food security and food sovereignty. The transformation of small scale farming } \\
\text { for subsistence and the local market to large scale agro-industrial soy } \\
\text { cultivation is a major threat to food sovereignty and food security [88,110]. } \\
\text { Health consequences due to the use of chemicals, either related to direct use } \\
\text { when spaying or handling chemicals, or indirectly through the contamination } \\
\text { of water and food [ } 88,110] \text {. } \\
\text { Consequences related to farmer's knowledge, rural development and cultural } \\
\text { diversity. The replacement of locally-adapted indigenous rice varieties by } \\
\text { industrially produced high response varieties [65,88] has led to a poor } \\
\text { knowledge base among rice farmers in such rice producing countries as India } \\
\text { and the Philippines. Poor farmer knowledge in the fields of local agricultural } \\
\text { conditions undermines health, rural development and cultural diversity } \\
\text { [42,88]. }\end{array}$ & $\begin{array}{l}\text { Food security and food sovereignty are improved as variations in the food } \\
\text { produced spread the environmentally-induced risks and allow subsistence } \\
\text { farming }[42,51,65,88] \text {. } \\
\text { Better health due to better diet (more nutritious and varied food, less } \\
\text { contaminated water) and the non-handling of chemicals [88,110]. } \\
\text { Farming of rice, based on traditional and inherited knowledge and developed } \\
\text { via the breeding of rice varieties adapted to local conditions, has a large } \\
\text { number of advantageous consequences. The farmers' local knowledge base is } \\
\text { secured and protects both the natural as well as the cultural resource base, as } \\
\text { subsistence food needs are met and the resistance to harsh environmental } \\
\text { conditions is strengthened }[42,51,65,88] \text {. }\end{array}$ \\
\hline
\end{tabular}


Table 2. Cont.

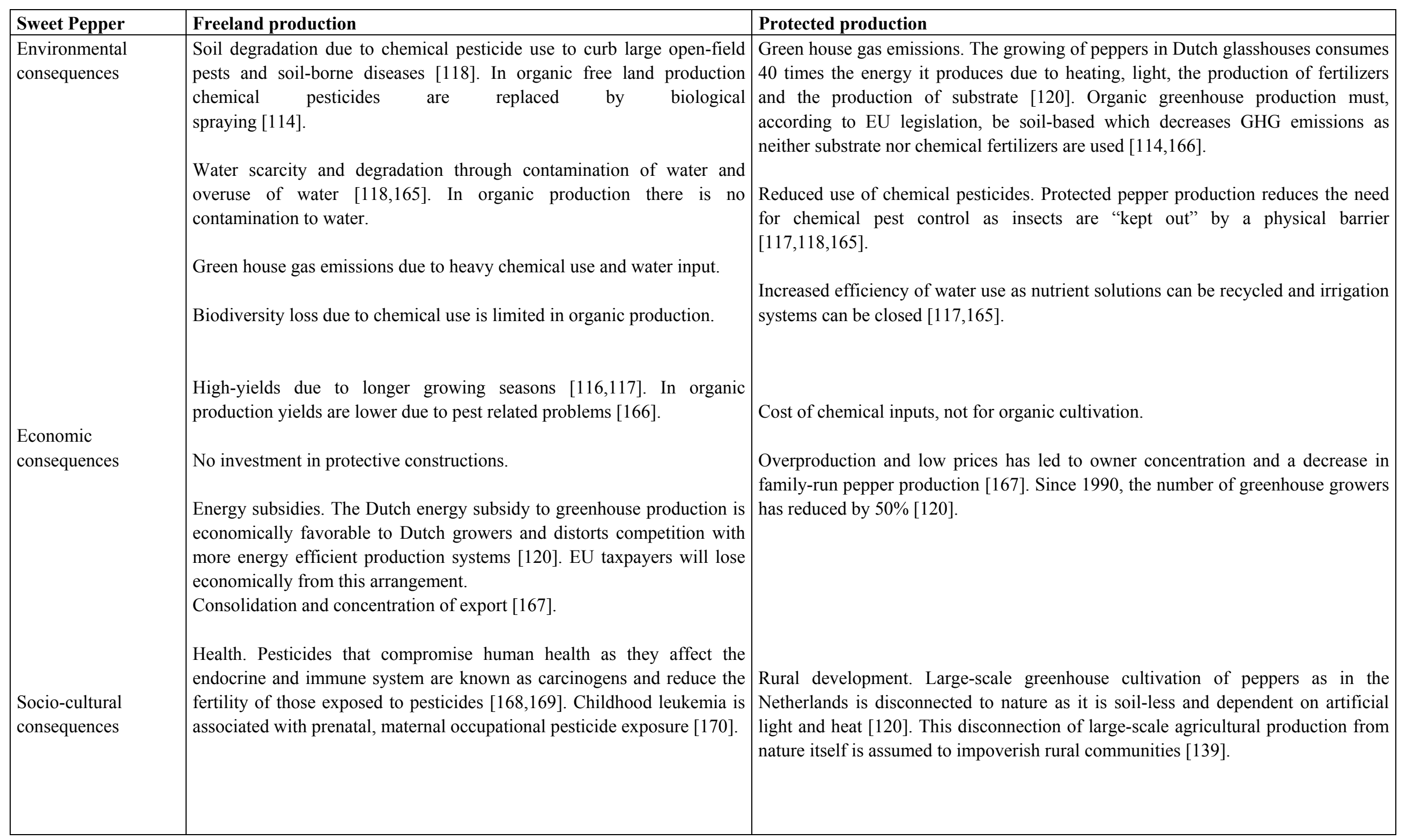


Table 2. Cont.

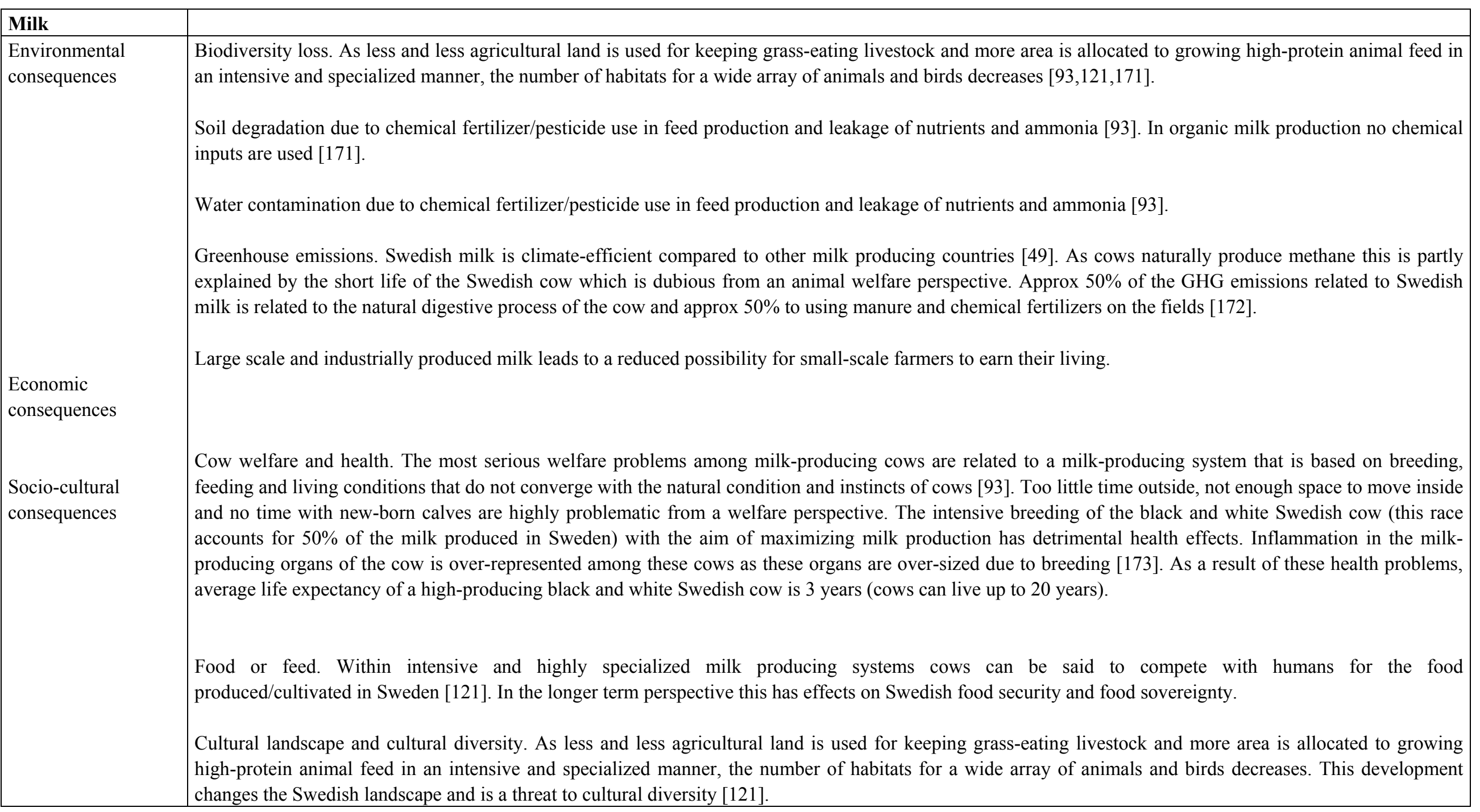


Table 3. Sustainable hot spot matrix for the production of six food products.

\begin{tabular}{lcccccccc}
\hline $\begin{array}{l}\text { Sustainable } \\
\text { hot spots }\end{array}$ & Climate & $\begin{array}{c}\text { Food and } \\
\text { water security }\end{array}$ & Biodiversity & $\begin{array}{c}\text { Cultural } \\
\text { diversity }\end{array}$ & $\begin{array}{c}\text { Protein } \\
\text { efficiency }\end{array}$ & Poverty & $\begin{array}{r}\text { Health } \\
\text { Animal } \\
\text { welfare }\end{array}$ \\
\hline Rice & $\mathrm{X}$ & $\mathrm{X}$ & $\mathrm{X}$ & $\mathrm{X}$ & & $\mathrm{X}$ & $\mathrm{X}$ & \\
Pork/soy & $\mathrm{X}$ & $\mathrm{X}$ & $\mathrm{X}$ & $\mathrm{X}$ & $\mathrm{X}$ & $\mathrm{X}$ & $\mathrm{X}$ & $\mathrm{X}$ \\
Salmon/fish & & $\mathrm{X}$ & $\mathrm{X}$ & $\mathrm{X}$ & $\mathrm{X}$ & $\mathrm{X}$ & & $\mathrm{X}$ \\
Sugar & $\mathrm{X}$ & $\mathrm{X}$ & $\mathrm{X}$ & $\mathrm{X}$ & & $\mathrm{X}$ & & \\
Sweet pepper & $\mathrm{X}$ & & $\mathrm{X}$ & & & & $\mathrm{X}$ & \\
Milk & $\mathrm{X}$ & & $\mathrm{X}$ & $\mathrm{X}$ & $\mathrm{X}$ & & & $\mathrm{X}$ \\
\hline
\end{tabular}

\subsection{Limitations of the Study}

One limiting factor in this study has been that no contacts were established with research centers working with sustainable production of pork, farmed salmon and milk. Such a possible bias could affect the possibility of properly categorizing the consequences of producing these foods. Biases and the selection of cases have implications on the validity of the proposed conceptualizations for food in general. The strong consistency in the patterns distinguished across cases labeled as climate, biodiversity, cultural diversity, poverty and food/water security indicate that these issues are an integral part of the contemporary Western food provisioning system in general, both in terms of agri-industrial production practices and sourcing. However, inclusions of additional cases might have added more nuances to the descriptions of sustainably-produced food presented in this article.

\section{Results}

Based on the descriptions of the sustainability-related consequences of the production of the six food products presented in Table 2, a sustainable hot spot matrix has been developed that summarizes and categorizes the sustainability-related consequences across cases. Patterns distinguished across cases are labeled as climate, food/water security, biodiversity, cultural diversity, protein efficiency, poverty, health and animal welfare.

\subsection{Hot Spot: Climate}

The climate category serves to label GHG emissions caused by food production. Production of all but one-farmed salmon based on fish feed-of the selected food products caused GHG emissions. For rice, milk, sugar, pork based on soy and sweet peppers, a large part of GHG emissions is due to the heavy use of chemical fertilizers and pesticides [125,129,130,157,172]. In food provision, the poly-cropbased production of rice, GHG emissions are reduced due to a low chemical dependence [157]. The biodiversity base of such traditional organic farming systems not only reduces GHG emissions but also fixes carbon in vegetation and soil [67]. In organic sugarcane production, GHG emissions are reduced as chemical inputs are avoided and residues from sugarcane are used to produce energy [125]. This ethanol substitution for fossil fuel in sugarcane results in decreased levels of GHG emission compared to sugar beet production. 
Other food-specific important sources of GHG emissions are the production of methane by the natural digestive process of cows used for Swedish milk production and by wetland rice production, the destruction of tropical rainforest and savannah in South America to produce soy used as feed in pig meat production, the production of methane, nitrous oxide and other gases (e.g., ammonia) related to pig farming and energy consumed for heating and lighting characteristic of protected (glasshouse) production of sweet peppers [120,125,129,130,133,157-159,172].

\subsection{Hot Spot: Food and Water Security}

The food and water security category implies that food production affects people's right to adequate food and water. The production of rice, pork based on soy feed, farmed salmon based on fish feed and sugar affects food security, as large-scale industrial production intended for competition on global markets requires land/fish formerly used for subsistence farming/fishing [88,89,110,127,129,130,140,152,153]. Poly-crop subsistence farming including livestock, i.e., agri-biodiverse subsistence farming, reduces environmentally-induced risks as variation in food sources is established [127]. Subsistence farming, like subsistence fishing, often includes selling surpluses in local markets, thereby reducing poverty. The conversion of land used for subsistence farming to the large-scale industrial production of soy, rice, or sugar is paralleled by decreased production of traditional food crops and is often accompanied by food price increases. In the case of Argentina, many Argentineans can no longer afford to eat meat and drink milk, as traditional pasture and farmland has been lost to soy production resulting in the importation of expensive foreign milk [132].

The food security-related consequences of industrial monocultures of, for example, soy, rice and sugar, are without exception paralleled by water security issues. Large-scale industrial farming, largely dependent on chemical fertilizers and pesticides, influences water quality through chemical contamination and the quantity of available water through irrigation and decreased soil moisture $[88,98,99,108,110,111,157]$. The water scarcity associated with highly-responsive varieties of industrial seeds in monoculture agriculture has two facets [129,132]. The heavy use of chemical fertilizers and pesticides when growing these highly-responsive industrial varieties affects soil vitality and moisture [88,109,112,157]. As soil water decreases, it must be replenished through irrigation or through rainwater [126]. The effects of large-scale monocultures on water quality and quantity are interconnected. Decreased soil vitality (i.e., decreased organic activity in soil) and less soil water availability (i.e., less water stored in soil) affects the soil's ability to filter and thus improve water quality [174].

\subsection{Hot Spot: Biodiversity}

The biodiversity category implies that food production affects one or more of the following three components of biodiversity: diversity of plant and animal species, diversity within a species and diversity of ecosystems [55,69]. 


\subsubsection{Monocultures of Plants and Seeds}

Monocultures of soy and rice are based on genetically similar, high-responsive seeds bred to be optimally productive when provided with chemical fertilizers, pesticides and large amounts of water [65]. Large-scale monocultures of soy, sugar and rice influence biodiversity negatively on all three levels [69];

- Diversity of plant and animal species. The heavy use of chemical inputs and water scarcity negatively influence soil life and diversity in flora and fauna $[65,88,98,99,129,132,160]$. Biodiversity restoration is an important dimension of organic sugarcane cultivation that is paralleled by increased soil water retention and the return of creeks [128,174]. The biodiversity loss due to chemical use in sweet pepper production is limited in organic production.

- Diversity within species. The seeds used are genetically similar, which reduces the biodiversity of the seed sown by displacing locally-bred varieties adapted to local conditions $[65,88,160]$. This genetic uniformity increases bio-pollution as crops are less resilient to pests, disease and weeds as these develop resistance to agrochemicals [88,161,163]. The two main biosafety issues related to seeds are: (1) herbicide-resistant genes that move to wild plants and create so-called super-pests and (2) "superpests" as results of the loss of predators and thus contributing to the emergence of pest-resistance [60,132,138,161]. This development is spurred by the use of GE crops, where the intensified use of Round-up (glyphosate) has increased the risk of herbicide resistance and changed the soil flora [60,132,138].

- Diversity of ecosystems. The land used for crop cultivation represents ecosystems that have become increasingly homogenous. The decrease in biodiversity in terms of number of plant and animal species and number of cultivated varieties affects the ecosystem as a whole [45]. Soy production is South America is one example of this, the monotonous landscape of corn in Iowa (the American Farm Belt) is another [46]. In the case of soy cultivation, destruction of the savannah is yet another example of decreased ecosystem diversity [89,129,132].

\subsubsection{Animal/Fish Husbandry}

Large-scale monoculture in animal/fish husbandry negatively affects biodiversity in a similar way. Uniformity of seeds is here replaced with genetic uniformity, as the genetic base is limited to breeding lines that maximize growth and meat or milk output $[69,83]$.

- Diversity of plant and animal species. The heavy use of chemical inputs in salmon farms and the contamination of water and land due to intensive livestock and fish farming (leakage of nutrients as well as organic animal waste in the form of ammonia and minerals) influence the diversity of plants and species in the sea and on land $[90,106,139,150]$. In addition, the production of farmed salmon negatively affects biodiversity of plant and animal species as (1) salmon farming is based on feed from depleted wild fish stocks and (2) the many escapees from fish farms cause falling numbers of wild salmon, as farmed fish compete with wild salmon for feed and habitat, transfer infections and parasites to the wild population and engage in genetically dubious interbreeding $[90,106]$. In addition, salmon farms are highly attractive to predators such as otters, 
seals, sea lions, fish-eating birds and mink, all of which are killed to ensure the productivity of fish farms [150].

- Diversity within species. Intensive livestock, dairy and fish farms are based on genetic uniformity. The large-scale production of pork, milk and farmed salmon uses only a few genetically very similar breeding lines chosen to maximize growth and output of meat and milk $[69,173]$. This small genetic base has negative implications for biodiversity as local breeds have been lost. Selective pig breeding, resulting in poor immune systems and unnatural growth that results in health problems, such as heart weakness, is spreading to the South as industrial breeds are exported to developing countries $[69,73,82,83]$. Production of Swedish milk is based largely on the intensive breeding of the black and white Swedish cow to maximize milk production, a policy that results in detrimental health effects [142]. In the production of farmed salmon, genetic uniformity of the farmed stock has detrimental consequences for the wild population. The industrial breeding lines of salmon have disadvantageous body characteristics (e.g., less streamlined bodies, shorter fins, reduced swimming performance and different heart configurations) that threaten the wild population as farmed salmon often escape and interbreed with wild salmon [155].

- Diversity of ecosystems. Loss of habitat is related to milk production and indirectly to the production of pig meat. As less agricultural land is used for keeping grass-eating livestock and more area is allocated to growing high-protein animal feed in an intensive and specialized manner, the number of habitats for a wide array of animals and birds decreases [93,121,171].

\subsection{Hot Spot: Cultural Diversity}

The cultural diversity category implies that food production affects the variety of human societies/cultures represented in the world. The production of rice, pork based on soy, farmed salmon based on fish feed, sugar and milk have direct effects on cultural diversity. As the relationship between culture and biodiversity is regarded as direct, all food production that affects biodiversity also affects the variety of culture [164]. Data supporting the impact on cultural diversity were only found for five of the studied food products. However, the negative impact on biodiversity related to the production of sweet pepper indicates that an alternative use of land (in the case of sweet pepper cultivation) would make other ways of life possible. Negative impacts on cultural diversity related to food production are caused by loss of land, loss of available fish stocks and change of agricultural practice to the detriment of small-scale farmers and indigenous people. In the case of soy and sugar, large-scale plantations threaten cultural diversity and negatively affect subsistence farming, as fewer crops are cultivated for direct food consumption and less livestock is kept [127,132,140]. In the case of rice, replacing locally adapted indigenous rice varieties with industrially bred high-responsive varieties in small-scale farms leads to less land used to produce food for direct consumption [65,88]. This replacement of locally adapted small-scale farming practices that provide farmers (and local markets) with varied food, with large-scale industrial monocultures using industrial seeds, leads to a loss of knowledge in rural communities. Examples of traditional agricultural knowledge linked to local conditions and fauna are poly-cropping, biological pest control and medicinal plants [140]. In the case of farmed salmon based 
on fish feed, rural coastal communities are undermined as the aqua-industrial fish production system is disconnected from development, employment and income in rural communities [106,107,151].

In South America, the disruption of rural communities has led to migration as landless farmers and unemployed agricultural workers move to the slums of big cities $[129,132]$. The same dismantling of rural communities has been observed in a Western context. In the Netherlands, pig farming, as a profession and agricultural practice, is no longer part of Dutch rural society and landscape [139]. Dutch industrial pig meat production is primarily situated in industrial clusters disconnected from rural areas and this large-scale pig farming practice undermines rural development, knowledge and income [139]. Swedish milk production also affects cultural diversity. As less agricultural land is used for keeping grass-eating livestock and more land is allocated to growing high-protein animal feed in an intensive and specialized manner, opportunities for small-scale farmers to earn livings is reduced $[93,121,171]$.

\subsection{Hot Spot: Protein Efficiency}

The protein efficiency category serves to group together the input-output efficiencies of producing foods of animal/fish origin. Protein efficiency is connected to the issue of how farmland can be used most efficiently to feed the world's growing population. Production of pork based on soy feed, milk and farmed salmon based on fish feed has implications for the input-output relationship between energy and protein and consequently for how farmland and fish stocks are used to produce protein for human consumption. When comparing milk, chicken, pork and beef in terms of their protein and food energy output for humans, with input defined as energy from fossil fuel and energy output as "output relative to food directly available to man" ([175], p. 109), milk is the most efficiently produced source of animal protein [175]. Pork based on soy feed is regarded as a source of protein that is inefficient, as the land where soy is produced could be used to produce cereals for human consumption. Thus measured as "land area or GHG emissions per unit of protein or calories, it is less efficient to feed grain to animals that we then eat, than it is for us to eat the grain directly" ([176], p. 42). For meat, the protein efficiency category is ultimately linked to dietary recommendation regarding how much animal protein we should/could eat to stay healthy. The relevance of this category in conceptualizing sustainable food production is based on the fact that a healthy diet includes approximately $50-100 \mathrm{~g}$ of meat per day and that the proportion of animal protein is $20 \%$ of the daily intake of protein for all of the world's population [73,177]. Such a shift in the current Western diet, in which $44 \%$ of the protein intake originates from animal products, a ratio that increases in line with GDP, would sustain a growing population and enable a larger intake of animal protein in poor countries [177].

The ratio of fish feed to farmed salmon output is three to one, i.e., it takes approximately three kilos of wild-caught fish feed to produce one kilo of farmed salmon [90,178,179]. The use of wild fish as feed in salmon farming is a sign of direct protein inefficiency, as some of the wild fish species used as feed could be used for direct human consumption [90]. The use of wild industrial fish stocks (not for human consumption) as feed affects feed supplies for predator fish, which has indirect implications for human consumption. For farmed fish as for meat, the protein efficiency category is ultimately linked to the ratio of how much protein from fish we should/could eat to sustain a growing population. As 
salmon farming is based on feed made from wild-caught fish, competition for protein between humans and farmed fish will occur in the future [106].

\subsection{Hot Spot: Poverty}

The poverty category captures the fact that food production affects poverty in monetary terms. Production of rice, pork based on soy feed, farmed salmon based on fish feed and sugar has implications for poverty. The poverty impacts of soy and sugar are related to concentration of land ownership and mechanization. Large-scale production of soy and sugar is made possible by the lease or purchase of land formerly used for subsistence farming with extra income from selling surplus production on the local market $[98,99,129,132,140]$. When small-scale farmers lose their land, they need to find income elsewhere and this search is aggravated by, in the case of soy, the shortage of employment opportunities in areas of highly mechanized industrial soy cultivation, a shortage that depresses salaries $[129,132,140]$. There is evidence that those who are already poor have become even poorer, due to the expansion of soy production in Brazil and Paraguay [90,132]. Debt peonage, i.e., slave-like working conditions, exist where farm workers are in debt to pay for housing, food, or equipment, making it impossible for them to leave the farms or plantations that employ them [130].

In addition, the relationship between sugar and poverty is evident at the national level, as competition between sugarcane cultivated in developing countries and sugar beets cultivated in the EU and USA is harsh [95,96,101]. This struggle over the right to sugar income takes many forms, including import quotas for sugar producers outside the EU and US markets and the dumping of beet sugar in developing countries $[95,98,100]$. This competition between sugarcane and sugar beet is to the considerable disadvantage of developing countries, as it negatively affects export earnings [95,98,127].

The relationship between salmon farming based on fish feed and poverty is indirect. The use of wild fish stocks as feed reduces income and employment in fisheries in developing countries, a situation expected to worsen in the future because of the effects of over-exploiting feed fish species on all kinds of wild fish stocks [152,153].

\subsection{Hot Spot: Health}

The health category captures the fact that food production (health issues related to food consumption are beyond the scope of this article) have negative impacts on human health. Health issues characteristic of the production of rice, pork based on soy feed and sweet peppers are identified in this study. The use of pesticides when producing soy, rice and sweet peppers directly threatens the health of people spraying or handling the chemicals, or indirectly through the contamination of water and food $[88,110,130]$. Pesticides compromise human health as they affect the endocrine and immune systems and reduce the fertility of those exposed to them $[168,169]$. In the case of soy, the use of highly toxic pesticides has led to an increasing number of cancer diagnoses in the Brazilian state of Mato Grosso [130]. Childhood leukemia is associated with prenatal, maternal occupational pesticide exposure [170].

Pork production is connected with serious health issues. The large-scale and highly intensive nature of industrial pork production is the source of infectious disease and drug-resistant bacteria that can spread to humans. Three quarters of confirmed emerging infectious human diseases are linked to the 
expansion and industrialization of meat farming [143,144]. Intensive confinement linked to high stocking densities, allowing no possibility for animals to move according to their instinct, lack of sunlight, stress-induced tail biting and poor hygienic conditions during castration, tail-docking and tooth-cutting are some examples of factors that suppress the immune systems of farmed pigs and make them susceptible to disease [145]. The 2005 outbreak of Streptococcus suis in Chinese industrial pig farms is an example of how virulent strains of disease can be related to intensive meat farming [146]. S. suis is now a common source of meningitis in farmed pigs and people worldwide [147]. Multidrug-resistant bacteria, causing antibiotic-resistant human disease, are linked to the use of antibiotics in industrial meat farming [148,149].

\subsection{Hot Spot: Animal Welfare}

The animal welfare category captures the effects on animal/fish welfare that are closely related to the production of pork, milk and farmed salmon. Negative effects on animal and fish welfare are correlated with highly intensive industrial production, based on selective breeding to maximize meat and milk output and with high stocking densities [80,90,50].

Welfare complications arise in pig farming due to selective breeding that maximizes output of pork but at the cost of excessive and unnatural growth resulting in heart weakness, leg deformities and weak immune systems that make pigs susceptible to bacteria and disease [73,80,82,142]. For cows, detrimental health effects such as inflammation in the milk-producing organs are over-represented in cows bred for maximum milk output, as their organs are over-sized due to selective breeding [173]. Due to these health problems, the average life expectancy of a high-producing black and white Swedish cow is three years (though cows can live up to 20 years). The living conditions of industrially farmed animal/fish further aggravate precarious welfare conditions related to breeding. The industrial production of pork occurs indoors, depriving the pigs of natural outdoor behavior [137]. In their natural conditions, pig sows live together in small groups and find an isolated and protected site in which to give birth; piglets are weaned and stay with their mothers for a minimum of 17 weeks [82]. In industrial indoor farming, piglets are separated from their mothers after 2-4 weeks and housed together. Routine mutilations such as castration, tail-docking and tooth-clipping are part of this farming system [80]. Pigs are kept on concrete or on straw. Breeding sows are kept in crates on concrete floors or on straw, often nose-ringed to prevent their instinctive nest-building and rooting behavior [82]. Swedish milk-producing cows in large-scale farms face welfare problems similar to those of pigs: they spend little time outside, have insufficient space in which to move and spend no time with their new-born calves [121]. For farmed salmon, the high numbers of fish in each cage cause several interrelated health and welfare problems [90,150]. Constraints to natural swimming behavior cause stress and aggression that result in increased susceptibility to disease and parasites, increased levels of physical injuries, reduced growth and feed intake and increased mortality $[90,150]$.

\section{Concepts Designed to Promote Consumption of Sustainably Produced Food}

The hot spots described above have been condensed into four concepts that capture present unsustainable traits in the production of the food studied while suggesting solutions to the very same problems. The concepts of biodiversity restoration, resource efficiency, local adaptation and welfare 
and rights restoration are the common solution-oriented denominators of the sustainable hot spots illustrated in Table 3. As such, they encompass all the integrated socio-cultural, environmental and indirect economic consequences (in terms of distribution of income and poverty) of the production of rice, pork based on soy feed, farmed salmon based on fish feed, sugar, sweet peppers and milk identified here. The concepts are interdependent and the relationships between consequences related to food production and the four concepts are illustrated in Table 4.

Sustainable food production as biodiversity restoring, resource efficient, locally adapted and welfare and rights restoring indicates that the conventional (i.e., non-organic) food production studied and to some extent the organic production studied, is characterized by the following: biodiversity loss; the inefficient use of resources to feed the world's growing population; the global scope of the food provision system, not only in terms of markets but primarily in its homogenous practice; and threats to the welfare and rights of humans and animals in this system. The above concepts have been formulated in accordance with the educational and empowering aspects of sustainable marketing [33-35]. The solution-oriented connotation of the word "restoring" (in terms of "biodiversity restoring" and "welfare and health restoring") evokes the sense that one is contributing to increased biodiversity, welfare and health as a consumer of sustainably produced food. The same logic applies to "resource efficient" and "locally adapted" as their opposites, i.e., inefficient and non-adapted, do have negative connotations. These words have been chosen to evoke the sense that one is contributing to the more efficient handling of resources in feeding the world and to the local adaption of farming as a consumer of sustainably produced food. The wording consciously emphasizes the possibility of making a difference by consuming sustainably produced food, as suggested in the sustainable marketing literature [33-35]. This way of conceptualizing sustainable food production is indirectly supported by research within the area of consumer policy where the empowering aspect of an individual ability to master change through exercising choice is emphasized [3]. The suggested conceptualization is meant to facilitate how consumers make sense of sustainable food by exploring and reflecting on different stakeholder positions related to food production $[25,26]$. Such reflection is encouraged by the wording of the concepts (biodiversity restoring, resource efficient, locally adapted and welfare and rights restoring), whose opposites explicitly frame food production as an activity with different interests at stake. However, the dialogue and interaction characteristics of communication circumscribe the transformative potential of information sent and shared by these concepts [27]. Thus empowerment of food consumers in terms of negotiating and constructing the meaning of sustainable food production is a process of communication that is dependent on how the concepts are used in a market setting. 
Table 4. Relation between consequences related to food production and the four concepts.

\begin{tabular}{|c|c|c|c|c|c|c|c|c|}
\hline Hot spot & Climate & Food and water security & Biodiversity & Cultural diversity & Protein efficiency & Poverty & Health & Animal welfare \\
\hline $\begin{array}{l}\text { Biodiversity } \\
\text { restoring }\end{array}$ & $\begin{array}{l}\text { Impacts on use of chemical } \\
\text { pesticides, deforestation and } \\
\text { carbon sequestration in } \\
\text { grazing. }\end{array}$ & $\begin{array}{l}\text { Impacts on poly cultures } \\
\text { of subsistence farming } \\
\text { securing varied food and } \\
\text { water access. Impacts on } \\
\text { water through habitat } \\
\text { restoration. }\end{array}$ & $\begin{array}{l}\text { Impacts on soil fertility, } \\
\text { plant and species variety } \\
\text { and habitat. }\end{array}$ & $\begin{array}{l}\text { Impacts on income } \\
\text { from small-scale } \\
\text { farming in rural } \\
\text { communities }\end{array}$ & $\begin{array}{l}\text { Impacts on the source } \\
\text { and percentage of } \\
\text { animal/fish protein in } \\
\text { human diets. }\end{array}$ & $\begin{array}{l}\text { Impacts on } \\
\text { income from } \\
\text { small-scale } \\
\text { farming in rural } \\
\text { communities. }\end{array}$ & $\begin{array}{l}\text { Impacts through } \\
\text { no use of } \\
\text { pesticides and } \\
\text { more disease } \\
\text { resilient livestock. }\end{array}$ & $\begin{array}{l}\text { Impacts on } \\
\text { animal/fish local } \\
\text { breeding of traditional } \\
\text { resistant } \\
\text { livestock/fish. }\end{array}$ \\
\hline $\begin{array}{l}\text { Resource } \\
\text { efficient }\end{array}$ & $\begin{array}{l}\text { Impacts on land use (food } \\
\text { instead of feed) and } \\
\text { production methods } \\
\text { minimizing energy from } \\
\text { fossil fuel and water } \\
\text { consumption. }\end{array}$ & $\begin{array}{l}\text { Impacts on food and water } \\
\text { access through traditional } \\
\text { /organic production } \\
\text { methods that are poly } \\
\text { cultural in nature. }\end{array}$ & $\begin{array}{l}\text { Impacts on soil vitality, } \\
\text { soil water, plant and } \\
\text { species variety through } \\
\text { traditional /organic } \\
\text { production methods that } \\
\text { are pesticide free. }\end{array}$ & $\begin{array}{l}\text { Impacts on small- } \\
\text { scale subsistence } \\
\text { farming promoting } \\
\text { development of rural } \\
\text { communities. }\end{array}$ & $\begin{array}{l}\text { Impacts on } \\
\text { calorie/protein output } \\
\text { per calorie of energy } \\
\text { input as energy and } \\
\text { nutrients are circulated } \\
\text { at the farm level. } \\
\text { Impacts on land use. }\end{array}$ & $\begin{array}{l}\text { Impacts on the } \\
\text { small-scale } \\
\text { farming enabling } \\
\text { income from } \\
\text { local markets. }\end{array}$ & $\begin{array}{l}\text { Impacts through } \\
\text { no use of } \\
\text { pesticides. }\end{array}$ & $\begin{array}{l}\text { Impacts on breeding } \\
\text { and livestock farming } \\
\text { methods, promoting } \\
\text { livestock adapted to } \\
\text { natural behavior and } \\
\text { local condition (e.g., } \\
\text { grazing). }\end{array}$ \\
\hline $\begin{array}{l}\text { Locally } \\
\text { adapted }\end{array}$ & $\begin{array}{l}\text { Impacts on use of chemical } \\
\text { inputs through traditional } \\
\text { methods, seeds and livestock } \\
\text { suitable for the local } \\
\text { condition. }\end{array}$ & $\begin{array}{l}\text { Impacts on suitable seeds } \\
\text { and livestock ensuring } \\
\text { disease resistance, } \\
\text { resilience and climate } \\
\text { change mitigation. }\end{array}$ & $\begin{array}{l}\text { Impacts through the } \\
\text { choice of locally adapted } \\
\text { plants and species and } \\
\text { traditional } \\
\text { /organic } \\
\text { farming methods. }\end{array}$ & $\begin{array}{l}\text { Impacts on small- } \\
\text { scale subsistence } \\
\text { farming promoting } \\
\text { development of rural } \\
\text { communities. }\end{array}$ & $\begin{array}{l}\text { Impacts on } \\
\text { calorie/protein output } \\
\text { per calorie of energy } \\
\text { input as energy and } \\
\text { nutrients are circulated } \\
\text { at the farm level. }\end{array}$ & $\begin{array}{l}\text { Impacts on the } \\
\text { yields and } \\
\text { possible side- } \\
\text { income of small- } \\
\text { scale farming. }\end{array}$ & $\begin{array}{l}\text { Impacts } \\
\text { through no use } \\
\text { of pesticides. }\end{array}$ & $\begin{array}{l}\text { Impacts on choice of } \\
\text { livestock adapted to } \\
\text { the local condition } \\
\text { and natural behavior } \\
\text { increasing health and } \\
\text { disease resistance. }\end{array}$ \\
\hline $\begin{array}{l}\text { Welfare and } \\
\text { rights } \\
\text { restoring }\end{array}$ & $\begin{array}{l}\text { Impacts on production } \\
\text { methods in livestock } \\
\text { farming- less dependence on } \\
\text { fossil fuel. }\end{array}$ & $\begin{array}{l}\text { Impacts on land use and } \\
\text { water quality as } \\
\text { livestock production is } \\
\text { changed. }\end{array}$ & $\begin{array}{l}\text { Impacts on local } \\
\text { breeding, suitable for } \\
\text { natural behavior, healthy } \\
\text { and disease resistant. }\end{array}$ & $\begin{array}{l}\text { Impacts on the } \\
\text { possibility to live in } \\
\text { rural areas and to } \\
\text { preserve cultural } \\
\text { variety in society. }\end{array}$ & $\begin{array}{l}\text { Impacts on the } \\
\text { intensity of live } \\
\text { stock/fish farming and } \\
\text { the amount of } \\
\text { animal/fish protein in } \\
\text { human diet. }\end{array}$ & $\begin{array}{l}\text { Impacts on the } \\
\text { possibility to } \\
\text { live in rural } \\
\text { areas and to } \\
\text { preserve cultural } \\
\text { variety in } \\
\text { society. }\end{array}$ & $\begin{array}{l}\text { Impacts through } \\
\text { less land used for } \\
\text { growing feed- } \\
\text { less use of } \\
\text { pesticides. }\end{array}$ & $\begin{array}{l}\text { Impacts on the ability } \\
\text { of animals/fish to live } \\
\text { in accordance with } \\
\text { their instincts. }\end{array}$ \\
\hline
\end{tabular}




\subsection{Sustainable Food Production is Biodiversity Restoring}

Biodiversity-restoring food production helps reverse the loss of diversity of plant and animal species, of varieties within species and in ecosystems $[55,62,69]$. The cornerstone of all aspects of biodiversity is soil fertility. Rebuilding soil fertility entails restoring the life of a multitude of microorganisms that contribute to soil fertility. As such, fertile soil is the very basis of sustainable food production and food security [67]. The relationship between soil fertility, plants and human and animal health can be described as [179]:

... a soil teeming with healthy life in the shape of abundant microflora and microfauna will bear healthy plants and these, when consumed by animals and man, will confer health on animals and man. But an infertile soil, that is, one lacking in sufficient microbial, fungal and other life, will pass on some form of deficiency to the plant and such a plant, in turn, will pass on some form of deficiency to animals and man ...

As illustrated in Table 4, the biodiversity restoring concept is related to a number of solutions to a great many sustainability problems concerning food production. Positive effects on the soil diversity in terms of organic matter, on the diversity of species, on the genetic diversity of crop and livestock and on habitats is a direct consequence of biodiversity-restoring food production. Biodiversity-restoring food production is incompatible with the use of Genetically Modified Organisms (GMOs), whose basis is genetic uniformity combined with heavy inputs of chemical pesticides/fertilizers and water. The effects on climate change are indirect: biodiversity-restoring production eschews fossil fuel-based pesticides, refrains from deforestation and the prevalence of rotational and extensive grazing ensures carbon sequestration $[46,176]$. Biodiversity-restoring food production promotes food and water security, as it is based on poly-cropping and the use of retained soil moisture (one prerequisite for soil fertility). Production of a variety of crops increases local access to varied food, reduces poverty and advances rural development and cultural diversity [55,88]. Water security is promoted, as farming methods refraining from chemical pesticides reduce water use. The hybrid seeds (i.e., high responsive varieties), typical of monocultures, are designed to produce food when provided with high inputs of chemicals and water. Biodiversity-restoring food production has effects on protein efficiency, as less energy (i.e., no chemical pesticides) is consumed to produce one calorie of food. Effects on animal welfare are related to a greater diversity of livestock and fish based on breeds adapted to local conditions and resistant to disease.

\subsection{Sustainable Food Production is Resource Efficient}

Resource-efficient food production promotes an efficient ratio between inputs of energy and water and output of calories/protein. The role of energy, nutrients and water illustrates possibilities for input substitution [179]:

Mother earth never attempts to farm without live stock; she always raises mixed crops; great pains are taken to preserve the soil and to prevent erosion; the mixed vegetable and animal wastes are converted into humus; there is no waste; the processes of growth and the processes of 
decay balance one another; the greatest care is taken to store the rainfall; both animal and plants are left to protect themselves against disease.

Resource-efficient food production is both input efficient, dependent on no or few inputs, i.e., chemical fertilizers/pesticides and irrigation water and output efficient, i.e., producing the maximum number of calories per hectare. Thus, resource-efficient food production promotes the use of agricultural land to produce human food instead of animal feed. Effects on GHG emissions and climate are direct, as resource-efficient food production minimizes dependence on fossil fuel. Food and water security is promoted, as resource-efficient farming is mostly small scale and diverse (i.e., a farming practice suitable for energy, nutrients and water), enabling subsistence farming and ensuring water access as part of traditional/chemical-free farming methods. Such small-scale organic farming methods can increase yields in the developing country context, which is characterized by low water and fertilizer inputs [70]. If developed properly, yields from small-scale organic farms can equal those of conventional farms in developed countries [71]. Diverse small-scale farms reduce poverty as they guarantee food security and generate side incomes as surpluses are saleable on the local market. Such rural income and employment have positive effects on cultural diversity.

By being biodiverse and chemical pesticide free, resource-efficient food production has positive effects on soil vitality, soil water and the diversity of plant and animal species and of habitats. Minimizing the ratio between inputs of energy and water and output of calories/protein, as is characteristic of resource-efficient food production, improves protein efficiency, since it promotes the growing of food for direct human consumption rather than of feed for animals. Resource-efficient food production improves animal welfare as well: as resource-efficient food production limits industrial high-intensive livestock farming, the negative animal welfare impacts stemming from industrial breeding and farming methods will be lessened.

\subsection{Sustainable Food Production is Locally Adapted}

Locally adapted food production is based on the plant species and varieties as well as farming practices that have evolved in local climates and under local conditions. As such, locally adapted food production ensures biodiversity in all its aspects. The localization of food production affects climate, as the use of chemical inputs is replaced with traditional farming methods. Food and water security is promoted as locally adapted seed and livestock are more disease resistant, increasing resilience and mitigating climate change. The predominance of small-scale locally adapted farms ameliorates poverty and promotes cultural diversity. Using traditional chemical-free food production methods positively affects yields and resilience and surpluses generate side-income from small-scale farming. The animal welfare impacts of locally adapted food production are related to the use of livestock breeds adapted to local conditions and the promotion of natural behavior, both of which improve health and disease resistance.

\subsection{Sustainable Food Production is Welfare and Rights Restoring}

Welfare- and rights-restoring food production promotes human and animal rights. Human rights in terms of access to food and water are secured, in a developing country context, by predominantly 
small-scale chemical-free subsistence-based farms serving local/regional markets. Such food production promotes biodiversity and cultural diversity, reduces GHG emissions, increases health and animal welfare and reduces poverty levels.

Animal rights are promoted, as industrial animal/fish farming is incompatible with animal welfare. Negative health effects due to industrial breeding, feeding cereals to grazing animals and high-density confinement indoors or in suspended cages (in the case of fish) are connected to an agri-industrial model of producing protein food. Restoring animal rights when producing animal/fish protein for human consumption will entail reductions in the amount of animal/fish protein in human diets.

\section{Conclusions}

This article addresses the question of how sustainably produced food can be described in order to promote the consumption of such food. Communication to promote sustainable food production and consumption as proposed by the conceptualization presented here challenge our understanding of food production. The institutionalized features of the market regarding (1) "organic" food production as always necessarily a better option than its conventional counterpart and (2) deeply-rooted convictions regarding the benefits of globalization are challenged by the suggested conceptualization. The concepts suggested as descriptors of sustainable food production to some extent discredit large-scale organic export-oriented food production based on mono-cropping, a system described as pseudo-organic or "big organic" [46,67]. The concepts of biodiversity restoration, resource efficiency, local adaptation and welfare and rights restoration characterize food production practice that is predominantly local/regional, small scale and poly-cultural, i.e., designed to cycle energy and nutrients and thus not dependent on inputs such as fertilizers and animal feed. Note that the wording of the suggested concepts is future-directed, indicating that we need to move in the direction of a food provision system that is largely based on small-scale bio-diverse family farms producing food for subsistence and/or the local market. Thus, the scope of the suggested concepts allows room for biodiversity-restoring, resource-efficient, locally adapted and welfare- and rights-restoring large-scale organic and fair-trade production of commodities that can only be produced in certain parts of the world. These commodities include tropical produce, such as sugarcane, bananas, coffee and cocoa. The concepts used to describe sustainably produced food provide strict guidelines for such food production, as it must not only restore biodiversity even in large-scale operations, but also contribute to food security and rural development and be based on the cycling of energy and nutrients.

The suggested concepts question the benefits of the present globalized food provision system in terms of the efficiency and distribution of calories it produces (i.e., food security). Large-scale export-oriented food production is input-inefficient due to dependence on fossil fuels in the form of chemical fertilizers and pesticides combined with high water usage.

The theoretical implications of this study concern how the proposed conceptualization and the understanding of advocated, sustainably produced food relates to other instruments designed for the promotion of sustainable food, such as eco-labeling and to structural conditions, such as the food provisioning system. The relationship between the proposed conceptualization of sustainable food and current eco-labeling schemes is complementary and yet contradictory. Consumer responses to eco-labels are described as; "paying attention to and understanding the new label depends on both 
consumer motivation and issue-relevant knowledge" ([1], p. 1802). Thus, educating consumers about sustainability issues and solutions connected to food production would increase their propensity to adopt eco-labels as a search-and-choice indicator in a supermarket setting. In this sense, the conceptualization of sustainable food proposed here would complement eco-labeling, as the concepts are designed to enhance consumer knowledge of food-related issues as well as their motivation through proposed sustainable solutions. In terms of consumers making sense of sustainable food as the negotiating of different perspectives, the suggested concepts can be considered as facilitators in the process of making sense of sustainable food production.

The proposed conceptualization renders transparent a number of conflicting interests regarding access to resources, the benefits of a global food system, how to define and organize organic food production and animal/human welfare. It is beyond the scope of this article to deal with the many conflicting goals that emerge when contrasting food eco-labels with the proposed conceptualization. However, conflict could arise concerning the kinds of food products deemed acceptable for eco-labeling schemes. Industrially produced meat (based on inputs of animal feed and housed indoors) and glasshouse-grown tomatoes in Northern Europe (where sunlight is scarce) exemplify products that, though labeled organic, cannot be considered sustainably produced according to the conceptualization proposed here. Another area of conflict between the proposed conceptualization of sustainably produced food and labeling schemes relates to global sourcing and food miles. Given the coherence in the literature concerning small-scale agricultural practice as the most efficient way out of poverty, hunger and cultural homogeneity in the South (as reflected in the wording of the concepts describing sustainably produced food), it is doubtful that long-distance transported food, whether eco-labeled or fair-trade-labeled, will contribute to sustainable food production in the long run. The transformative potential of within-market certification-based labeling schemes is contradictory [180]. Empirical evidence indicates several dilemmas that must be dealt with, as "the inclusion of marginalized producers and the production of mainstream quality products are organizational tasks which cannot be realized simultaneously because they contradict each other" ([180], p. 121). The example of fair trade banana exports subordinating social to quality goals indicates that the global sourcing of sustainably labeled products does not possess the transformative potential needed to change food production and consumption practice [180].

The conceptualization of sustainable food production suggested here can be used by policy makers and businesses to educate citizens and consumers about food production and sustainable development, as well as encourage changes in food consumption practice. The conceptualization can serve as a basis for communicating with food consumers in a way that nurtures their sense of change mastery and sense of belonging, as suggested by self-determination theory [3,23]. However, as stated by numerous consumer policy researchers, consumers alone cannot effect change. The structures of the food supply system, in terms of sourcing, supply and price, in many respects define and circumscribe consumer practice and the possibility to change consumer practice through marketing based activities $[3,4]$. Future research in this area will find challenges in investigating how, in an experimental or real-world context, the proposed concepts affect consumers' sense-making in relation to sustainable food. Also, research is needed to describe the different options regarding how concepts are presented, e.g., in-store $v s$. out-of-store information, product/product-group related or generic information, company-specific or industry-generated and the effects on consumers' understanding of sustainable food. Future research 
to investigate the relationship between consumers' perception of price and their understanding of sustainable food will help us understand the economic rationales for consuming food. Such an understanding, of the balance between price and understanding of sustainable food production, from a consumer perspective could offer numerous possibilities of marketing sustainable food.

\section{References}

1. Thorgersen, J. Country differences in sustainable consumption: The case of organic food. J. Macromark. 2010, 30, 171-185.

2. Tischner, U.; Kjaernes, U. Sustainable Consumption and Production in the Agriculture and Food Domain. In System Innovation for Sustainability 3. Case Studies in Sustainable Consumption and Production. Food and Agriculture; Tischner, U., Sto, E., Kjernes, U., Tukker, A., Eds.; Greenleaf Publishing: Sheffield, UK, 2010; pp. 6-41.

3. Thorgersen, J. How may consumer policy empower consumers for sustainable lifestyles. J. Consum. Policy 2005, 28, 143-178.

4. Fine, B.; Leopold, E. The World of Consumption; Routhledge: London, UK, 1993.

5. Spaargaren, G. Sustainable consumption-A theoretical and environmental policy perspective. Soc. Nat. Resour. 2003, 16, 687-701.

6. Arnould, E.; Thompson, C. Consumer culture theory CCT: Twenty years of research. J. Consum. Res. 2005, 31, 868-882.

7. FiBL and IFOAM. The World of Organic Agriculture-Statistics and Emerging Trends; IFOAM: Bonn, Germany, 2010.

8. FiBL and IFOAM. The World of Organic Agriculture-Statistics and Emerging Trends; IFOAM: Bonn, Germany, 2011.

9. Thorgersen, J.; Haugaard, P.; Olesen, A. Consumer responses to ecolabels. Eur. J. Mark. 2010, 44, 1787-1810.

10. Leire, C.; Thidell, Å. Product-related environmental information to guide consumer purchasesA review and analysis of research on perceptions, understanding and use among nordic consumers. J. Clean. Prod. 2005, 13, 1061-1070.

11. Csutora, M.; Zsoka, A. Maximizing the efficiency of greenhouse gas related consumer policy. J. Consum. Policy 2011, 34, 67-90.

12. Torjusen, H.C.; Kjaernes, U.; Sangstad, L.; O’Doherty Jensen, K. European Consumers' Conceptions of Organic Food; Professional Report 4; National Institute for Consumer Research: Oslo, Norway, 2004.

13. Tukker, A. Sustainability: A Multi-Interpretative Notion. In System Innovation for Sustainability 1, Tukker, A., Charter, M., Vezzoli, C., Sto, E. anderson, M., Eds.; Greenleaf Publishing: Sheffield, UK, 2008; pp. 14-45.

14. Darnton, A. Practical Guide: An Overview of Behavior Change Models and their Uses; HM Treasury Publishing Unit, Government Social Research Behavior Change Knowledge Review: London, UK, 2008.

15. Hargreaves, T. Practicing behavior change: Applying social practice theory to pro-environmental behavior change. J. Consum. Cult. 2011, 11, 79-99. 
16. Biel, A.; Larsson, M.; Gärling, T. Köpbeteendets Psykologi: Miljömedvetenhet Och Vanor. In Den Flerdimensionelle Konsumenten, Ekström, K., Forsberg, H., Eds.; Tre Böcker: Stockholm, Sweden, 1999; pp. 129-147.

17. von Borgstede, C.; Andersson, K. Environmental information-Explanatory factors for information behavior. Sustainability 2010, 2, 2785-2798.

18. Fransson, N.; Gärling, G. Environmental concern: Conceptual definitions, measurement methods and research findings. J. Environ. Psychol. 1999, 19, 369-382.

19. Söderholm, P. Hållbara hushåll: Miljöpolitik och ekologisk hållbarhet $i$ vardagen; Naturvårdsverket: Stockholm, Sweden, 2008; Rapport 5899.

20. Ericsson, L.; Garvill, J.; Nordlund, A.M. Acceptability of travel demand management measures: The importance of problem awareness, personal norm, freedom and fairness. J. Environ. Psychol. 2006, 26, 15-26.

21. Wolff, F.; Schönherr, N. The impacts evaluation of sustainable consumption policy instruments. J. Consum. Policy 2006, 34, 43-66.

22. Pape, J.; Rau, H.; Fahy, F.; Davies, A. Developing policies and instruments for sustainable household consumption: Irish experiences and futures. J. Consum. Policy 2011, 34, 25-42.

23. Deci, E.L.; Ryan, R.M. Intrinsic Motivation and Self-Determination in Human Behavior; Plenum Press: New York, NY, USA, 1985.

24. Dervin, B. Sense-making theory and practice: An overview of user interests in knowledge seeking and use. J. Knowl. Manag. 1998, 2, 36-46.

25. Dervin, B.; Foreman-Wernet, L.; Lauterbach, E. Sense-Making Methodology Reader. Selected Writings of Brenda Dervin; Hampton Press: New York, NY, USA, 2003.

26. Varey, R. A dialogical foundation for marketing. Mark. Rev. 2003, 3, 273-288.

27. Varey, R. Marketing as an interaction system. Aust. Mark. J. 2008, 16, 79-94.

28. Deetz, S. Democracy in an Age of Corporate Colonization. Developments in Communication and the Politics of Everyday Life; State University of New York Press: Albany, NY, USA, 1992.

29. Gadamer, H. Truth and Method; Seabury Press: New York, NY, USA, 1975.

30. Rubik, F.; Scholl, G.; Biedenkopf, K.; Kalimo, H.; Mohaupt, F.; Söebech, O. Innovative Approaches in European Sustainable Consumption Policies; Schrieftenreihe des IÖW 192/09; IOW: Berlin, Germany, 2009

31. Shove, E.; Pantzar, M. Recruitment and reproduction: The careers and carriers of digital photography and floorball. J. Hum. Aff. 2007, 17, 154-167.

32. Röpke, I. Theories of practice-New inspiration for ecological economic studies on consumption. Ecol. Econ. 2009, 68, 2490-2497.

33. Martin, D.; Schouten, J. Sustainable Marketing; Pearson: Upper Saddle River, NJ, USA, 2011.

34. Ottman, J.M. The New Rules of Green Marketing; Greenleaf Publishing: London, UK, 2011.

35. Belz, F.-M.; Peattie, K. Sustainability Marketing. A Global Perspective; John Wiley \& Sons, Ltd.: Chichester, UK, 2009.

36. Driscoll, C.; Starik, M. The primordial stakeholder: Advancing the conceptual considerations of the natural environment's stakeholder status. J. Bus. Ethics 2004, 49, 55-73.

37. Dolan, P. The sustainability of "sustainable consumption". J. Macromark. 2002, 22, 170-181. 
38. Connolly, J.; Prothero, A. Sustainable consumption: Consumption, consumers and the commodity discourse. Consum. Mark. Cult. 2003, 6, 275-291.

39. Schaefer, A.; Crane, A. Addressing sustainability and consumption. J. Macromark. 2005, 25, 76-92.

40. Prothero, A.; McDonagh, P.; Dobscha, S. Is green the new black? Reflections on a green commodity discourse. J. Macromark. 2010, 30, 147-159.

41. World Commission for the Environment and Development. Our Common Future; Oxford University Press: Oxford, UK, 1987.

42. The Institute for Sustainable Development (ISD). Finding out about Cultural Diversity: A First Guidebook; ISD: Addis Abbeba, Ethiopia, 2004.

43. American Public Health Association (APHA). Toward a Healthy, Sustainable Food System; APHA: Washington, DC, USA, 2007; Policy number 200712.

44. Schäfer, M.; Herde, A.; Kropp, C. Life Events as Turning Points for Sustainable Nutrition. In System Innovation for Sustainability 3. Case Studies in Sustainable Consumption and Production. Food and Agriculture; Tischner, U., Sto, E., Kjernes, U., Tukker, A., Eds.; Greenleaf Publishing: Sheffield, UK, 2010; pp. 210-227.

45. Shiva, V. Biopiracy. The Plunder of Nature and Knowledge; South End Press: Boston, MA, USA, 1997.

46. Pollan, M. The Omnivores Dilemma; Bloomsbury: London, UK, 2006.

47. United Nations. The Millennium Development Goals; UN: New York, NY, USA, 2008.

48. World Bank. Agriculture for Development; World Development Report 2008; World Bank: Washington, DC, USA, 2008.

49. FAO. Green House Gas Emissions from the Dairy Sector; FAO: Rome, Italy, 2010.

50. FAO. Volontary Guidelines to the Right to Food; FAO: Rome, Italy, 2005.

51. FAO. Organic Agriculture, Environment and Food Security, Environment and Natural Resources; Sustainable Development Program: Rome, Italy, 2002.

52. Holland, N.; Joensen, L.; Maeyens, A.; Samulon, A.; Semino, S.; Sonderegger, R.; Rulli, J. The Round Tables on Ir-Responsible Soy; ASEED Europe: Amsterdam, The Netherland, 2008.

53. BASE Investigaciones Sociales. The Refugees of the Agroexport Model; BASE: Humaitá, Brazil, 2008.

54. Friends of the Earth International. Trade and People's Food Sovereignty; Friends of the Earth International: Amsterdam, The Netherlands, 2003.

55. Frison, A.F.; Cherfas, J.; Hodgkin,T. Agricultural biodiversity is essential for a sustainable improvement in food and nutrition science. Sustainability 2011, 3, 238-253.

56. International Labour Office (ILO). Global Report on Child Labour; ILO: Geneve, Switzerland, 2002.

57. International Labour Office (ILO). The End of Child Labour: Within Reach; ILO: Geneve, Switzerland, 2006.

58. Swedish Society for Nature Conservation. Mat, klimat och utveckling; SNF: Stockholm, Sweden, 2007.

59. Wivstad, M. Kemiska bekämpningsmedel i svenskt jordbruk—användning och risker för miljö och hälsa; Centrum för uthålligt jordbruk, SLU: Ulltuna, Sweden, 2005. 
60. Benbrook, C.M. Genetically engineered crops and pesticide use in the United States: The first nine years; Ag BioTech InfoNet: Sandpoint, ID, USA, 2004.

61. Millennium Ecosystem Assessment. Ecosystems and Human Well-Being; Island Press: Washington, DC, USA, 2005.

62. Munang, R.T.; Thiaw, I.; Rivington, M. Ecosystem management: Tomorrow's approach to enhancing food security under changing climate. Sustainability 2011, 3, 937-954.

63. Falkenmark, M.; Rockström, J. Is There Sufficient Water to Eradict Hunger Worldwide? In Agriculture, Trade and Development, KSLA: Stockholm, Sweden, 2007.

64. IAASTD. Agriculture at a Crossroad. International Assessment of Agricultural Knowledge, Science and Technology for Development; IAASTD: Johannesburg, South Africa, 2008.

65. Shiva, V. Genetic Modification and Frankenstein Foods; Navdanya: New Delhi, India, 2000.

66. The International Federation of Organic Agriculture Movements (IFOAM). High Sequestration, Low Emission, Food Secure Farming. Organic Agriculture-A Guide to Climate Change \& Food Security. IFOAM: Bonn, Germany, 2009.

67. Shiva, V. Soil Not Oil. Climate Change, Peak Oil and Food Insecurity; Women Unlimited: New Delhi, India, 2009.

68. Swedish Society for Nature Conservation. Ekologiskt $i$ Etiopien-odling i samspel med naturen ger ökad lönsamhet och bättre riskspridning; SNF: Stockholm, Sweden, 2008.

69. Gura, S. Industrial Livestock Production and Biodiversity. In The Meat Crisis, D'Silva, J., Webster, J., Eds.; Earthscan: London, UK, 2010; pp.57-80.

70. UNEP-UNCTAD. Organic Agriculture and Food Security in Africa; UNEP-UNCTAD: Geneva, Switzerland, 2008.

71. Badgley, C.; Moghtader, J.; Quintero, E.; Zakem, E.; Chappell, J.; Aviles-Vásquez, K.; Samulon, A.; Perfecto, I. Organic agriculture and the global food supply. Renew. Agric. Food Syst. 2007, 22, 86-108.

72. Niggli, U.; Fliessbach, A.; Hepperly, P.; Scialabba, N. Low Greenhouse Gas Agriculture: Mitigation and Adaption Potential of Sustainable Farming Systems; FAO: Rome, Italy, 2009.

73. McMichael, A.J.; Butler, A.J. Environmentally Sustainable and Equitable Meat Consumption in a Climate Change World. In The Meat Crisis, D’Silva, J., Webster, J., Eds.; Earthscan: London, UK, 2010; pp.173-190.

74. Compassion in world farming. Global Warning: Climate Change and Farm Animal Welfare; Compassion in World Farming: Surrey, UK, 2008.

75. Capy, S.A.; Kobel, W.; Doe, J. Health risks of low-dose pesticide mixtures: A reviews of the 1985-1998 literature on combination and health risk assessment. J. Toxicol. Environ. Health Part B 2000, 3, 1-25.

76. Bellingham, M.; Fowler, P.; Amezaga, M.; Rhind, S.; Cotinot, C.; Mandon-Pepin, B.; Sharpe, R.; Evans, N. Exposure to a complex cocktail of environemnatl endoctrine-disrupting compounds disturbs the kisspeptin/GPR54 system in ovine hypothalamus and pituitary gland. Environ. Health Perspect. 2009, 117, 1556-1562.

77. Swedish Society for Nature Conservation. Rädda Liv. Byt Kaffe, SNF: Stockhol, Sweden, 2006.

78. Nilsson, J. Ekologisk produktion och miljökvalitetsmålen—en litteraturgenomgång, Centrum för uthålligt jordbruk, SLU: Uppsala, Sweden, 2007. 
79. Corr, J. The effect of morphology on walking ability in the modern broiler. Anim. Welf. 2003, 12, 159-171.

80. D'Silva, J. Adverse impact of industrial animal agriculture on the health and welfare of farmed animals. Integr. Zool. 2006, 1, 53-58.

81. Sustain: The Alliance for Better Food and Farming. In Sustainable Food in Care Catering; Sustain: London, UK, 2006.

82. Compassion in World Farming. Stop-Look-Listen. Recognising the Sentience of Farm Animals; Compassion in World Farming: Surrey, UK, 2003. Available online: www.ciwf.org.uk (accessed on 15 February 2012).

83. FAO. State of the World's Animal Genetic Resources; FAO: Rome, Italy, 2007.

84. Rawles, K. Developing Ethical, Sustainable and Compassionate Food Policies. In The Meat Crisis, D’Silva, J., Webster, J., Eds.; Earthscan: London, UK, 2010; pp. 209-227.

85. Yin, R.K. Case Study Research; Sage: Thousands Oaks, CA, USA, 2002.

86. Patton, M. Qualitative Evaluation and Research Methods; Sage: Newbury Park, CA, USA, 1990.

87. Eisenhardt, K. Building theories from case study research. Acad. Manag. Rev. 1989, 14, 532-550.

88. Bachman, L.; Cruzada, E.; Wright, S. Food Security and Farmer Empowerment-A Study of the Impacts of Farmer-Led Sustainable Agriculture in the Philippines; Misereor/MASIPAG: Laguna, Philippines, 2009.

89. Compassion in World Farming. Pig Welfare-Towards Shared Priorities for the Future; Compassion in World Farming: Surrey, 2008; Report 2008. Available online: http://www.ciwf.org.uk (accessed on 15 February 2012).

90. Stevenson, P. Closed Waters: The Welfare of Farmed Atlantic Salmon, Rainbow Trout, Atlantic Cod \& Atlantic Halibut; Report by Compassion in World Farming, 2007. Available online: www.ciwf.org.uk (accessed on 15 February 2012).

91. Wielgosz, B. Like Shooting Fish in a Barrel; 2005. Available online: http://www.sustainweb.org (accessed on 15 February 2012).

92. OECD-FAO. Agricultural Outlook 2010-2011; 2011. Available online: http://www.agri-outlook. org (accessed on 15 February 2012).

93. Swedish Dairy Association. Mjölken och miljömålen. 2010. Available online: http://www.svenskmjolk.se (accessed on 15 February 2012).

94. FAO. Food Outlook. Global Market Analysis. Sugar; FAO: Rome, Italy, 2009.

95. Oxfam. Dumping on the World. How EU Sugar Policies Hurt Poor Countries; Oxfam: Oxford, UK, 2004; Oxfam Briefing Paper no. 61. Available online: http://www.oxfam.org/ (accessed on 15 Fenruary 2012).

96. Axelsson-Nycander, G.; Jonasson, A. EU, Sockret och Utvecklingen (The EU, Sugar and Development); Lutherhjälpen: Stockholm, Sweden, 2006.

97. KSLA. Socker i global handel, jordbruk och folkhälsa. KSLA:s Tidskrift 2006, 145, 11-42.

98. Oxfam. A Sweeter Future; Oxfam: Oxford, UK, 2004; Briefing Paper no. 70. Available online: www.oxfam.org/en/policy/a-sweeter-future (accessed on 15 February 2012).

99. World Wildlife Fund (WWF). Action for Sustainable Sugar; WWF: Washington, DC, USA, 2005. Available online: http://www.panda.org/freshwater/sugar (accessed on 15 February 2012). 
100. FAO. Sugar: The Impact of Reforms to Sugar Sector Policies-A Guide to Contemporary Analyses; FAO Trade Policy Technical Notes; FAO: Rome, Italy, 2005.

101. International Sugar Organisation. Quarterly Market Outlook; International Sugar Organisation: London, UK, 2002.

102. Institut Für Angewandte Urbanistik (IFAU). The European Red Meat Industry-Present State and Factors Shaping the Future; IFAU: Uppsala, Sweden, 2010.

103. World Bank. Livestock Development-Implications for Rural Poverty, the Environment and Global Food Security, World Bank: Washington, DC, USA, 2001.

104. Subasinghe, R. Aquaculture Development-The Blue Revolution. In Fisheries, Sustainability and Development; Stockholm Environmental Institute: Stockholm, Sweden, 2009; pp. 281-301.

105. FAO. State of World Aquaculture; FAO: Rome, Italy, 2006; FAO Fisheries Technical Paper no. 500.

106. Kiessling, A. Feed-The Key to Sustainable Fish Farming. In Fisheries, Sustainability and Development; Stockholm Environmental Institute: Stockholm, Sweden, 2009; pp. 303-324.

107. Ababouch, L. Fish Utilization and Trade. In Fisheries, Sustainability and Development, Stockholm Environmental Institute: Stockholm, Sweden, 2009; pp. 377-398.

108. Lansing, S. Volcanic fertilization of Balinese rice paddies. Ecol. Econ. 2001, 38, 383-390.

109. Reynolds, J. Cycle of Rice. A Story of Sustainable Farming; Lee \& Low Books Inc: New York, NY, USA, 2009.

110. Shiva, V. Manifestos on the Future of Food and Seed; South End Press: Cambridge, UK, 2007.

111. Personal interview, Navdanya biodiverse and organic farm, Dehradun, India, 2010.

112. Shiva, V. Water Wars. Privatization, Pollution and Profit; India Research Press: New Delhi, India, 2002.

113. FAO. Available online: http://faostat.fao.org (accessed on 15 February 2012).

114. Personal interview, Lois Bolk Institute, the Netherlands, 2010

115. Bertuglia, A.; Calava-Reguera, J. Factors Related to the Adoption of Good Agrarian Practices GAP in Plastic Covered Horticulture of Southeastern Spain. In Proceedings of the International Association of Agricultural Economics Annual Meeting, Queensland, Australia, 12-18 August 2006.

116. Cantliffe, D.; Vansicke, J. Competitiveness of the Spanish and Dutch greenhouse industries with the Florida Fresh Vegetable Industry. Proc. Fla. State Hort. Soc. 2001, 114, 121-135.

117. The United States Department of Agriculture (USDA). Greenhouse-Grown Bell Pepper Production; USDA: Washington, DC, USA, 2005. Available online: http://www.usda.org (accessed on 15 February 2012).

118. Weintraub, P. Integrated control of pests in tropical and subtropical sweet pepper production. Pest Manag. Sci.2007, 63, 753-760.

119. Wagening University, Organic Knowledge Update, October 2009.

120. Swedish National Radio. Matens Pris; Swedish National Radio: Stockholm, Sweden, 28 February 2010.

121. Swedish Society for Nature Conservation. Djur och Betesmark; SNF: Stockholm, Sweden, 2010.

122. Glaser, B.; Strauss, A. The Discovery of Grounded Theory; Strategies for Qualitative Research, Aldine Publishing Co.: Chicago, IL, USA, 1967. 
123. Strauss, A. Qualitative Analysis for Social Scientists; Cambridge University Press: New York, NY, USA, 1990.

124. Land Research Action Network. The WTO and the Destructive Effects of the Sugarcane Industry in Brazil; 2006. Available online: http://www.landaction.org/display.php?article=405 (accessed on 15 February 2012).

125. Seabra, J.; Macedo, I. Energy Balance and GHG Emissions in the Production of Organic Sugar and Ethanol at Sao Fransisco Sugar Mill; FEM/UNICAMP: Rua Mendeleyev, Brazil, 2010.

126. Native. Sustainability Profile; 2008. Available online: http://www.nativeorganics.com.br (accessed on 15 February 2012).

127. FAO. From Subsistence Farming to Sugar-Cane Monoculture: Impacts on Agrobiodiversity, Local Knowledge and Food Security; FAO: Rome, Italy, 2008.

128. Miranda, J.R.; Miranda, E.E. Biodiversity and System of Organic Production Recommendation for Sugar Cane; Report EMBRAPA: Campinas, Brazil, 2004.

129. Holland, N.; Joensen, L.; Maeyens, A.; Samulon, A.; Semino,S.; Soneregger, R.; Rulli, J. The Round Table on Ir-Responsible Soy; Report, La Soja Mata. 2008. Available online: http://www.lasojamata.org (accessed on 15 February 2012).

130. Swedwatch. Mer kött och soja, mindre regnskog; Swedwatch: Stockholm, Sweden, 2010.

131. World Resources Institute. Climate Analysis Indicators Tool CAIT Version 4.0; World Resources Institute: Washington, DC, USA, 2007. Available online: http://cait.wri.org./ (accessed on 15 February 2012).

132. Joensen, L.; Semino, S.; Paul, H. Agentina: A Case Study on the Impact of Genetically Engineered Soya; The Gaia Foundation: London, UK, 2005. Available online: http://www.gaiafoundation.org (accessed on 15 February 2012).

133. FAO. Livestock Policy Briefing; FAO: Rome, Italy, 2006.

134. Compassion in World Farming. Sustainable Agriculture; Compassion in World Farming: Surrey, UK, 2008. Available online: http://www.ciwf.org.uk (accessed on 15 February 2012).

135. Hoekstra, A. The Water Footprint of Animal Products. In The Meat Crisis; D'Silva, J., Webster, J., Eds.; Earthscan: London, UK, 2010; pp. 22-34.

136. Compassion in World Farming. Reducing Meat Consumption-The Care for Urgent Reforms; Compassion in World Farming: Surrey, UK, 2004. Available online: http://www.ciwf.org.uk (accessed on 15 February 2012).

137. Swedish Society for Nature Conservation. Kött—Övergödning och Klimat; SNF: Stockholm, Sweden, 2008.

138. Bonny, S, Herbicide-tolerant transgenic soy-bean over 15 years of cultivation: Pesticide use, weed resistance and some economic issues. The case of the USA. Sustainability 2011, 3, $1302-1322$.

139. McMichael, P. Food system sustainability: Questions of environmental governance in the new world disorder. Glob. Environ. Change 2011, 21, 804-812.

140. Palau, T.; Cabello, D.; Mayeyns, A.; Rulli, J.; Segovia, D. The Refugees of the Agroexport Model; BASE Investigaciones Sociales: Asuncion, Paraguay, 2007. Available online: http://www.lasojamata.org (accessed on 15 February 2012). 
141. Steward, C. From colonization to environmental soy: A case study of environmental and socio-economic valuation in the Amazon soy frontier. Agric. Hum. Values 2007, 24, 102-122

142. Swedish National Radio. Matens Pris, Swedish National Radio: Stockholm, Sweden, 7 March 2012.

143. Woolhouse, M.E.; Gowtage-Sequeria, S. Host range and emerging and reemerging pathogens. Emerg. Infect. Dis. 2005, 11, 1842-1847.

144. WHO/FAO/OIE. Report of the WHO/FAO/OIE Joint Consultation on Emerging Zoonotic Diseases; 2004. Available online: http://www.whqlibdoc.who.int/hq/2004/ WHO_CDS_CPE_ZFK_2004.9.pdf (accessed on 15 February 2012).

145. Greger, M. Industrial Animal Agriculture's Role in the Emergence and Spread of Disease. In The Meat Crisis; D’Silva, J., Webster, J., Eds.; Earthscan: London, UK, 2010; pp.161-173.

146. World Health Organization (WHO). Streptococcus Suis, Fact Sheet; WHO: Geneva, Switzerland, 2005. Available online: http://www.wpro.who.int/media_centre/fact_sheets/fs_20050802.htm (accessed on 15 February 2012).

147. Huang, Y.T.; Teng, L.J.; Ho, S.W.; Hsueh, P.R. Streptococcus suis infection, J. Microbiol. Immunol. Infect. 2005, 38, 306-313.

148. Goldberg, R.; Roach, S.; Wallinga, D.; Mellon, M. The risks of pigging out on antibiotics. Science 2008, 321, 1294.

149. Smith, G.J.; Vijaykrishna, D.; Bahl, J.; Lycett, S.J.; Worobey, M,; Pybus, O.G.; Ma, S.; Cheung, C.L.; Ragwani, J.; Bhatt, S.; Peiris, J.S.M.; Guan, Y.; Rambaut, A. Origins and evolutionary genomics of the 2009 swine-origin H1N1 influenza: A epidemic. Nature 2009, 459, $1122-1125$.

150. Lymbery, P. In Too Deep. The Welfare of Intensively Farmed Fish; Compassion in World Farming Trust: Surrey, UK, 2002. Available online: http://www.ciwf.org.uk (accessed on 15 February 2012).

151. Terram. Salmon Farming in Chile-Environmental and Social Conflicts, Terram: Santiago de Chile, Chile, 2005. Available online: http://www.terram.cl (accessed on 15 February 2012).

152. Kébé, M. Taking Contribution of Fisheries into Account in Development Policy, In Fisheries, Sustainability and Development; Stockholm Environmental Institute: Sockholm, Sweden, 2009; pp. 365-376.

153. Béné, C.; Macfadyen, G.; Allison, E.H. Increasing the Contribution of Small-Scale Fisheries to Poverty Alleviation and Food Security; FAO Fisheries Technical Paper No. 481; FAO: Rome, Italy, 2007.

154. University of Strathclyde. The Salmon Farming Industry. Cooperation vs. Competetion for Achieving a Global Position; Case study, Ref. No. 506-153-1; University of Strathclyde: Glasgow, UK, 2006.

155. Thorstad, E.B.; Fleming, I.A.; McGinnity, P.; Soto, D.; Wennevik, V.; Whoriskey, F. Incidence and Impacts of Escaped Farmed Atlantic Salmon Salmo Salar in Nature; Special Report 36; NINA: Trondheim, Norway, 2008. Available online: http://www.nina.no (accessed on 15 February 2012).

156. World Health Organization (WHO). Food Safety Associated with Products from Aquaculture; Technical Report Series; WHO: Geneva, Switzerland, 1999; No 883. 
157. International Federation of Organic Agriculture Movements (IFOAM). The Contribution of Organic Agriculture to Climate Change Mitigation; IFOAM: Bonn, Germany, 2009.

158. Neue, H. Methane Emissions from Rice Fields. Wetland rice fields may make a major contribution to global warming. BioScience 1993, 43, 466-473.

159. Uprety, D.C.; Baruah, K.K.; Borah, L. Methane in rice agriculture: A review. J. Sci. Ind. Manag. 2011, 70, 401-411.

160. Andersson, L. Genetic Engineering, Food and Our Environment; Green Books: Totnes, UK, 1999.

161. Shiva, V. Biopollution and Biosafety, Lok Swaraj Series on Natural Resources and Peoples Rights, Navdanya: New Delhi, India, 2000.

162. GRAIN. Planthoppers Crash China's Hybrid Rice Party; Hybrid rice blog, GRAIN: Barcelona, Spain, December 2009. Available online: http://www.grain.org/hybridrice/index.cfm? blog\&print=yes (accessed on 24 March 2010).

163. GRAIN. Rice Grabs Undermine Food Sovereignty in Africa; GRAIN: Barcelona, Spain, 2009. Available online: http://www.grain.org/articles/index.cfm?id=46 (accessed on 24 March 2010).

164. Shiva, V.; Bedi, G. Sustainable Agriculture and Food Security. The Impact of Globalization; Sage: Thousand Oaks, CA, USA, 2002.

165. Jovicich, E.; Cantliffe, E.; Sargent, S.; Osborne, L. Production of Greenhouse Grown Peppers in Florida; University of Florida: Gainesville, FL, USA, 2005.

166. Sukkel, W.; Hommes, M. Research on organic agriculture in the Netherlands; Wagening UR and Lois Bolk Institute: Amsterdam, The Netherland, 2009.

167. Cook, R. Super Market Challenges and Opportunities for Fresh Fruit and Vegetable Producers and Shippers: Lessons from the U.S Experience. In Proceedings of the Conference on Supermarkets and Agricultural Development in China-Opportunities and Challenges, Shanghai, China, 24 May 2004.

168. Perry, M. Effects of environmental and occupational pesticide exposure on human sperm: A systematic review. Hum. Reprod. Update 2008, 14, 233-242.

169. Dennis, L.; Lynch, C.; Sander, D.; Alavanja, M. Pesticide use and cutaeous melanoma in pesticide applicators in agricultural health study. Environ. Health Perspect. 2010, 118, 812-817.

170. Wigle, D.T., Turner, M.; Krewski, D. A systematic review and meta-analysis of childhood leukemia and parental occupational pesticide exposure. Environ. Health Perspect. 2009, 117, 1505-1513.

171. KRAV. KRAV och klimat. 2009. Available online: http://www.krav.se/Om-KRAV/ Fordjupande-lasning-/Miljo/KRAV-och-klimat/ (accessed on 24 March 2010).

172. Cederberg, C.; Flysjö, A; Sonesson, U.; Sund, V.; Davis, J. Greenhouse Gas Emissions from Swedish Production of Meat, Milk and Eggs 1990 and 2005; SIK Report No 793; SIK: Göteborg, Sweden, 2009.

173. Swedish National Radio. Matens pris, Swedish National Radio: Stockholm, Sweden, 14 March 2010.

174. Personal interview, Native Produtos Organicos, Riberao Preto, Brasil, 2010.

175. Webster, J. Food from the Dairy: Husbandry Regained. In The Meat Crisis; D'Silva, J., Webster, J., Eds.; Earthscan: London, UK, 2010; pp. 99-117. 
176. Garnett, T. Livestock and Climate Change. In The Meat Crisis; D'Silva, J., Webster, J., Eds.; Earthscan: London, UK, 2010; pp. 34-57.

177. Compassion in World Farming. Eating the Planet? How can We Feed the World without Trashing it?; Compassion in World Farming: Surrey, UK, 2009. Available online: http://www.ciwf.org.uk (accessed on 15 February 2012).

178. Shepherd, C.J.; Pike, I.H.; Barlow, S.M. Sustainable Feed Resources of Marine Origin. In Proceedings of the Conference: Lessons from the Past to Optimize the Future, European Aquaculture Society; 2005; Special Publication no. 35.

179. Howard, Sir Albert. An Agricultural Testament; Oxford University Press: New York, NY, USA, 1943.

180. Gandenberger, C.; Garrelts, H.; Wehlau, D. Assessing the effects of certifications networks on sustainable production and consumption: The cases of FLO and FSC. J. Consum. Policy 2011, $34,107-126$.

(C) 2012 by the authors; licensee MDPI, Basel, Switzerland. This article is an open access article distributed under the terms and conditions of the Creative Commons Attribution license (http://creativecommons.org/licenses/by/3.0/). 